\title{
O SIMULACRO DA ALTERIDADE: UMA ANÁLISE DISCURSIVA DO RITUAL DE EXORCISMO DA IGREJA UNIVERSAL DO REINO DE DEUS
}

\author{
Jaçanã Ribeiro ${ }^{I}$ \\ "Se uma pessoa chegar à Igreja no momento \\ em que as pessoas estão sendo libertas, poderá pensar \\ que estão em um centro de macumba, eparece mesmo." \\ Edir Macedo
}

\section{INTRODUÇÃO A DEMONIZAÇÃO DAS RELIGIÕES AFRO}

Esse texto, antes de se inscrever na atual produção antropológica e sociológica sobre a relação entre o neopentecostalismo, em especial da Igreja Universal, e as religiōes afro, busca contribuir para o estudo da relação entre as formas de ilusão de reversibilidade e a heterogeneidade do discurso religioso $^{2}$. O ritual de exorcismo dessa igreja será abordado aqui a partir de uma perspectiva da análise da linguagem própria ao discurso que sustenta essa prática religiosa. Assim sendo, ao investigar o modo como os sujeitos dessa prática interp retam sua relação com o sagrado, abordarei a heterogeneidade do discurso religioso iurdiano, mais propriamente a ten-

\footnotetext{
${ }^{1}$ Mestre em Estudos da Linguagem, UFRGS.

${ }^{2}$ Apresento aqui alguns pontos principais de uma análise mais ampla que desenvolvi durante a preparação da dissertação de mestrado em Análise do Discurso, intitulada $O$ simulacro da alteridade: uma análise discursiva do ritual de libertação e cura da Igreja Universal do Reino de Deus.
} 
são entre o caráter autoritário desse discurso, que tende a estancar a polissemia, e a presença de seu outro, que remete os sentidos para sua exterioridade, para a intertextualidade constitutiva desse discurso; como se sabe, a existência do ini migo central de todos rituais da IURD - o encosto é dada como sempre já-lá, vindo de outro lugar, de outro discurso. É portanto com base na dependência à exterioridade que constitui todo enunciado que apresento uma análise do fenômeno da possessão neopentecostal como um ritual discursivo em que a presença do outro (entidade possessora) só ocorre na dependência do Outro (discurso).

Esta análise do discurso neopentecostal incide justamente sobre a relação conflituosa que o discurso da IURD mantém com o discurso das religióes afro, relação essa que interpreto como uma relação interdiscursiva da qual investigo o funcionamento. Assim, ainda que partindo de um lugar teórico específico, que é a Análise do Discurso de tradição francesa, se busca dialogar com as interpretaçóes da chamada "guerra santa" produzidas no campo da literatura antropológica e sociológica. Tomo tais interpretações como parâmetro para basear a hipótese de que é possível isolar um espaço discursivo em que estão em relação o discurso da IURD e o das religiôes afro. A partir desse conhecimentointerdisciplinar, proponho a especificidade do olhar discursivo sobre o objeto, a fim de produzir uma análise das formas materiais (lingüístico-d iscursivas) desse conflito inscritas no ritual discursivo de exorcismo, entendendo-o como um ponto nevrálgico da relação entre os dois discursos, como uma instância de tradução que um faz do discurso do outro.

Nesse sentido, o ritual de exorcismo é o ponto chave para a análise da heterogeneidade do discurso iurdiano. Como dizem os especialistas, o neopentecostalismo se afasta do pentecostalismo tradicional dada a ênfase na ação do diabo. Tendo a IURD como principal representante, nos seus cultos o ritual de exorcismo terá um papel fundamental na arregimentação de fiéis e na sustentação de sua doutrina. A centralidade da figura do diabo faz com que o ritual de exorcismo constitua um dos pilares do discurso da IURD.

Nas reuniōes de terça e sexta-feira (Sessão do Descarrego e Corrente de 
Libertação), mediante uma "oração forte", os pastores da IURD invocam as entidades das religiōes afro para estas se manifestarem no corpo dos fiéis como formas diferentes do diabo, para depois serem exorcizadas, expulsas do templo diretamente para o inferno. É essa situação conflituosa, repetida estrutu ralmente, que leva alguns antropólogos a falarem de "guerra santa", ou "guerra espiritual" para se referirem à in tolerância religiosa da IURD.

Segundo o fundador da igreja, bispo Edir Macedo, em seu best-seller "Orixás, Caboclos e Guias: deuses ou demônios": "Tudo o que existe de ruim neste mundo tem sua origem em satanás e seus demônios. São eles os causadores de todos os infortúnios que atingem o homem direta ou indiretamente" (Macedo, 2002, p. 103). Conseqüentemen te, Edir Macedo acredita que sua igreja tem o papel de libertar as pessoas dos espíritos opressores que não são nada mais que disfarces do diabo para enganá-las:

"Com nomes bonitos e cheios de aparatos, os demônios vêm enganando às pessoas com doutrinas diabólicas. Chamam-se orixás, caboclos, pretos-velhos, guias, espíritos de luz, etc. Dizem-se ser exus, erês, espíritos de crianças, médicos famosos, poetas famosos, etc., mas na verdade são anjos decaídos" (Macedo, 2002, p. 32).

As reuniōes de libertação e cura, nessa lógica, teriam como objetivo desmascarar as religiōes afro como veículos do diabo no mundo atual, como canais de atuação dos demônios. Para o bispo Macedo, "essa religião (afrobrasileira) que está tão popular no Brasil é uma fábrica de loucos e uma agência onde se tira o passaporte para a morte e uma viagem para o inferno" (Macedo, 2002, p. 86).

Nos exorcismos, os fiéis possuídos por uma entidade, entre eles antigos praticantes das religiōes afro, submetem-se a um interrogatório em que são, na maioria das vezes, ridicularizados pelos pastores, chegando até a bater a cabeça no chão, numa imitação grotesca do que ocorre nos terreiros. Através desse interrogatório, que faz parte do ritual que é objeto da análise, as entidades se identificam como sendo entidades afro, com objetivos malignos contra o fiel no qual estão encarnadas. O pastor então exorciza o demô- 
nio, com a legitimidade do Espírito Santo, e derrota assim o poder do Mal, ali representado como entidade das religiōes afro-brasileiras.

Paradoxalmente, esse ataque constante, ao invés de distanciar a IURD de seu inimigo, acabou por torná-la mais parecida com ele. De fato, chegase a designar a IURD como representante de um "neopentecostalismo macu mbeiro", dada a apropriação do universo simbólico das religiōes afro na própria estrutura ritual da IURD. Outros autores, como a antropóloga $\mathrm{Pa}$ trícia Birman, tratam o conflito como resultante de uma ponte, de uma passagem, entendida como um espaço de interlocução constante, necessariamente fluido e sincrético, de redefinição de fronteiras, inovaçôes, invençóes e trocas simbólicas (Birman, 1996, p. 90). Já para Ronaldo de Almeida, tratase de um processo de inversão simbólica e "adoção de alguns dos mecanismos de funcionamento da fé inimiga" (Almeida, 2003, p. 336), que ao invés de corroborar para simples negação do sentido contrário, acaba por legitimar certos aspectos da religiáo combatida, tal como a veracidade do que ocorre na umbanda e no candomblé. Nesse sentido, os rituais de exorcismo da IURD assumiriam uma função estrutural de contra-feitiço, através do combate daquilo que, em parte, a igreja incorporou a sua doutrina. Em termos de preparação doutrinária, decorre da condição de eficácia desse ataque a necessidade de tanto os pastores e bispos como os próprios fiéis dominarem princípios do neopentecostalismo e também das religiōes afro, o que leva algunsautores afirmarque "naIURD, no Candomblé e na Umbanda se fala uma mesma linguagem” (Soares apud Oro, 2004, grifo nosso).

Nesse sentido, no processo de demonização das religióes afro por parte do neopentecostalismo "a IURD não nega a existência das entidades afrobrasileiras, mas modifica o seu significado" (Oro, 1997, p. 15). Ao fazê-lo, tal processo acaba por contribuir para acentuar sua singularidade no campo cristão e evangélico, uma vez que o próprio Edir Macedo faz uma distinção entre Igreja Forte e Igreja Fraca: Igreja Forte seria aquela que, como a IURD, luta contra o demônio, não na defensiva, mas o ataca, libertando as pessoas das "garras do diabo". Se entende daí a designação de igreja religiofágica (Oro, 1997) que se lhe atribui, pois além de incorporar "pedaços de crenças” das religiōes afros, a IURD também dialoga com a Igreja Católica, que 
reputa como Ig reja Fraca, para refutar seus posicionamentos "apáticos". Nessa lógica, a singularidade da IURD no meio cristão e evangélico residiria nessa tarefa espiritual: "nossa igreja foi levantada para um trabalho especial, que se salienta em todas as nossas reunióes - a libertação de pessoas endemoniadas" (Macedo, 2002, p. 16).

Com relação ao diálogo conflituoso com as religiōes afro, afirma Oro (1997):

"a ênfase no exorcismo dos demônios - identificados com o panteão religioso afro-brasileiro - que perturbam as pessoas causando-lhes os males, constitui um importante código de diferenciação, um sinal diacrítico da identidade neopentecostal, especialmenteda IURD. Para esta, o afro-brasileiro representa a alteridade radical, que contribui, por contraste, para a construção da sua própria identidade religiosa. Na prática, porém, as fronteiras entre essas expressões religiosas são, em certos aspectos, fluidas e porosas" (Oro, 1997, p. 20 - grifos meus).

Como uma in terpretação desse "compartilhamento" de uma "mesma linguagem", Ari Pedro Oro (1996), ao citar Segato, propóe entender-se a construção da unidade dividida da identidade da IURD como proveniente de uma re-semantização, um processo que ocorre quando conteúdos das religiōes de origem, vindas de fora, são alterados por conteúdos das localidades e dos grupos que os adota. É a partir dessa re-semantização que os significados próprios das religiōes afro são transformados nas práticas da IURD. Sem pretender deslegitimar essa explicação, proponho a visada discursiva, recusando entender as práticas religiosas como exteriorizaçōes de conteúdos, mas como discursivizaçôes de saberes conflitantes em práticas determinadas sócio-históricamente por formações discursivas (FDs) em relação. O objetivo é então precisar o funcionamentodiscursivo da interlocução e da inconstância das fronteiras entre os discursos da IURD e das religióes afro, aprofundando o tratamento da re-semantização através do exame do processo de "tradução" específico que ocorre entre as formaçôes discursivas da IURD e das religióes afro, produzindo o que chamo de simulacro da alteridade do discurso iurdiano. 
Sem ser exaustivo na exposição das interpretações antropológicas e sociológicas do conflito entre IURD e religióes afro, apresentei apenas algumas interpretações que considero extremamente valiosas para o objetivo do trabalho. Em seu conjunto, elas permitem ver nesse conflito a ênfase da heterogeneidade constitutiva do discurso neopentecostal da IURD. Ao propor explicações sobre a relação dialógica entre IURD e religiões afro, muitos autores falam em "interlocuçáo constante", "redefiniçáo de fronteiras", "limites fluidos e porosos", etc. Ao analisar o ritual de libertaçáo e cura da IURD, parto da existên cia material do exterio $r$ e anterio $r$ ao dito, o interdiscurso, a memóriado dizível,tal como foi definidopor Pêcheux(1995), para ter na materialidade lingüística a materialidade específica do objeto discurso. Vê-se que é propriamente a determinação desse exterior ao dito que, segundo a perspectiva discursiva, permite explicitar os contornos fluidos e porosos dos dois "sistemas religiosos", a partir do momen to em que se tem como foco a heterogeneidade constitutiva dos discursos.

\section{O RITUAL DE LIBERTAÇÃO E CURA COMO RITUAL DISCURSIVO}

O neopentecostalismo é tomado aqui, portanto, não sob o viés etnográfico ou sociológico apenas, mas é entendido como um discurso religioso, tal como a Análise do Discurso tem definido essa tipologia de discurso, dando ênfase para a relação entre língua, ideologia e sujeito.

Para Orlandi (1987) o discurso religioso é um discurso autoritário, pois há apenas ilusão de reversibilidade entre locutor e ouvinte. Caracterizado como aquele em que o homem faz falar a voz de Deus no silêncio onipotente desse, o discurso religioso é marcado por um desnivelamento entre locutor, do plano divino (o Sujeito, Deus), e ouvinte, do plano temporal (os sujeitos, os homens).

Corrêa (1989) aponta a ritualização do discurso como propriedade básica do discurso religioso, servindo à oposição entre o que é do plano temporal e o que é do plano divino: 
"No caso do discurso religioso, a ritualização tem a ver portanto, com a sua configuração em relação com o que lhe é exterior. Ou seja, as falas submetidas ao ritual lingüístico derivam do que a realidade estabelece como sagrado, mantendo uma relação de exclusão com toda fala não ritualizada em direção ao sagrado. Em outras palavras, o discurso religioso se estabelece no estranhamento da linguagem cotidiana - virtualmente ritualizada pelo/para o mundano - assumindo para si a ritualização tida como legítima para o sagrado e até atribuída à divindade" (Corrêa, 1989, p. 29-30).

Paraexaminar a relaçãoentre IURD e religiōesafro, analisoa ritualização não de uma de suas reuniões em particular, mas o que é comum a duas dessas reuniōes, a saber, o ritual de libertação e cura, que se dá na forma de exorcismo, tanto na Sessão de Descarrego, das terças-feiras, quanto na Corrente de Libertação, que ocorre nas sextas-feiras. Assim, o exorcismo, presente em ambas as reunióes, será abordado como ritual discursivo próprio ao discurso religioso neopentecostal da IURD. Quanto à análise do ritual, procuro não restringi-la à reiteração de processos lingüísticos cristalizados pela instituição, mas também determinar as condições de seu funcionamento, das regras impostas aos sujeitos que o praticam. Nesse sentido, a análise do ritual de libertação e cura, enquanto uma prática discursiva, pode ser aproximada da análise dos sistemas de rarefação dos sujeitos com direito à palavra legitimada, dos quais Foucault fala em $A$ ordem do discurso:

"A forma mais superficial e mais visível desses sistemas de restrição é constituída pelo que se pode agrupar sob o nome de ritual; o ritual define a qualificação que devem possuir os indivíduos que falam (e que, no jogo de um diálogo, da interrogação, da recitação, devem ocupar determinada posição e formular determinado tipo de enunciados); define os gestos, os comportamentos, as circunstâncias, e todo o conjunto de signos que devem acompanhar o discurso; fixa, enfim, a eficácia suposta ou imposta das palavras, seu efeito sobre aqueles aos quais se dirigem, os limites de seu valor de coerção" (Foucault, 200133, p. 38-39).

${ }^{3}$ Ano de publicação da 7a . edição. O original é de 1970.

Debates do NER, Porto Alegre, ano 6, N. 7, P. 11-78, JAN./Jun. 2005 
Segundo a Análise de Discurso, o conjunto do dizível é definido, historicamente, para o sujeito, pela relação entre formações discursivas (FDs) distintas, que definem, para uma posição de sujeito, aquilo que pode e deve ser dito (Pêcheux, 1995, p. 160). Essa redefinição da noção de FD de Foucault tem o propósito de dar conta do caráter material do sentido das palavras e dos enunciados da língua, de sua opacidade histórica. Uma das teses mestras de Pêcheux, em Semântica e Discurso (1995) é a de que

"o sentido de uma palavra, de uma expressão, de uma proposição, etc., não existe 'em si mesmo' (isto é, em sua relação transparente com a literalidade do significante), mas, ao contrário, é determinado pelas posições ideológicas que estão em jogo no processo sócio-histórico no qual as palavras, expressões e proposiç̧ôes são produzidas (isto é, reproduzidas)(...) as palavras, expressões, proposições, etc., mudam de sentido segundo as posições sustentadas por aqueles que as empregam" (Pêcheux, 1995, p. 160).

O discurso é pensado como um dos aspectos materiais da existência material das ideologias, sendo o ponto de encontro entre língua e ideologia. Ideologia aqui pensada como interpretação em determinado sentido, marcando no discurso (na língua e na história) o posicionamento do sujeito frente à injunção a significar sua relação com a realidade natural e social. O direcionamento ideológico está então na injunção a uma interpretação que se apresenta como $a$ interpretação. Desse modo, a FD é ao mesmo tempo: a matriz do sentido (produtora da evidência do sentido, do efeito de transparência da linguagem) e lugar da constituição do sujeito (como causa de si, origem do sentido) do discurso.

Pêcheux designará por processo discursivo "o sistema de relações de substituição, paráfrases, sinonímias, etc., que funcio nam entre elementos lingüísticos - significantes - em uma formação discursiva dada" (Pêcheux, 1995, p. 161). O processo discursivo em uma FD será determinado, de seu exterior, pelo "todo complexo com dominante" das FDs, o interdiscurso como exterior específico da FD. Para Pêcheux, o próprio de toda FD é dissimular sua dependência ao interdiscurso, intrincado no complexo das 
formações ideológicas, dissimulando, na transparência do sentido que nela se forma, a objetividade material contraditória do interdiscurso (Pêcheux, 1995, p. 162).

O funcionamentodo interdiscurso na constante reorganizaçãodas fronteiras das FDs é o que fornece "a cada sujeito" sua "realidade", enquanto sistema de evidências e de significações percebidas-aceitas-experimentadas, sem que este perceba sua dependência ao exterior constitutivo de seu dizer e de sua identidade. Dois efeitos, que marcam a determinação do interdiscurso sobre a FD e assim a inter-relação entre discurso e língua, explicitam a constituição do "enunciável como exterior ao sujeito":

a) o pré-construido: introduzido por P. Henry, designa uma construção anterior, exterior, independente, por oposição ao que é construído na enunciação. Marca a discrepância entre o interdiscurso como lugar de constituição do pré-construído e o intradicurso, como lugar da enunciação de um sujeito. O pré-construído "corresponde ao 'sempre-já-aí" da interpelação ideológica que fornece-impóe a 'realidade' e seu 'sentido' sob a forma da universalidade (o mundo das coisas e seus sentidos)" (Pêch eux, 1995, p. 164). A noção de pré-construído é imprescindível para a análise da determinação exterior que constitui o discurso da IURD, ou seja, a determinação de sua relação com o discurso das religiōes afro.

b) a articulação de enunciados: o interdiscurso funciona também como "discurso-transverso", atravessando e pondo em relação en tre si elementos pré-construídos no intradiscurso, a partir dos quais o sujeito enunciador dá coerência ao fio do discurso. $\mathrm{O}$ intradiscurso de uma seqüência discursiva aparece assim como um efeito do interdiscurso sobre si mesmo (Pêcheux, 1995, p. 167). Ao analisar a sintaxe própria ao ritual de libertação e cura, a noção de discurso-transverso revela a produção de efeitos de sentido que singularizam a relação entre o discurso da IURD e o interdiscurso.

Ambos são funcionamentos que determinam a forma-sujeito do discurso:

“diremos que a forma-sujeito (pela qual o 'sujeito do discurso' se identifica com a FD que o constitui) tende a absorver-esquecer o interdiscurso no

Debates do NER, Porto Alegre, ano 6, N. 7, p. 11-78, JAn./Jun. 2005 
intradiscurso, isto é, ela simula o interdiscurso no intradiscurso, de modo que o interdiscurso aparece como o puro "já-dito" do intradiscurso, no qual ele se articula por co-referência. Parece-nos, nessas condiçóes, que se pode caracterizar a forma-sujeito como realizando a incorporação-dissimulação dos elementos do interdiscurso" (Pêcheux, 1995, p. 167 - grifos meus).

A noção de sujeito para a $\mathrm{AD}$, duplamente determinado (pela ideologia e pelo inconsciente) se enriquece assim em sua complexidade: a partir de uma FD heterogênea, a forma-sujeito sofre um desdobramento em diferentes posiçôes-sujeito, que evidenciam diferentes formas de se relacionar com a forma-sujeito, instaurando o lugar da divisão e da diferença, assim como o lugar possível da resistência. Assim, as condições de produção do discurso, que num primeiro momento eram fechadas no espaço de uma FD em sua relação com o interdiscurso, vão sofrer modificações a partir das reflexôes de Courtine (1981).

Apresentando uma noção de FD cujas fronteiras são instáveis em relação ao interdiscurso que a determina, fazendo com que essa obedeça, ao mesmo tempo, a um princípio de aceitabilidade e a um princípio de exclusão, Courtine redefine a FD como o domínio do que pode e dever ser dito, mas também do que não pode e não deve ser dito (Courtine, 1981) em uma conjuntura dada.

"O interd iscurso de uma FD deve ser pensado como um processo de reconfiguração incessante a partir do qual o saber de uma FD é conduzido, em função das posições ideológicasque essa FD representa em uma conjuntura determinada, a incorporar elementos pré-construídos produzidos no seu exterior; a produzir sua redefinição ou retorno; a suscitar igualmente a lembrança de seus próprios elementos, a organizar sua repetição, mas também a provocar eventual mente o apagamento, o esquecimento ou mesmo a denegação desses elementos. O interdiscurso de uma FD, como instância de formação/repetição/transformação dos elementos de saber dessa FD, pode ser apreendido como o que rege o deslocamento de suas fronteiras" (Courtine, 1981, p. 49, minha tradução). 
Courtine abre assim a possibilidade de análise de enunciados cujas condiçôes de produção sejam diferentes daquelas do conjunto de enunciados em foco (produzidos sobre CPs homogêneas), enfatizando portan to a heterogeneidade de uma FD sob a dominância de outra ou outras FDs com as quais mantém relações de contradição, antagoniso, aliança, recobrimento, etc. A noção de posição-sujeito, assim, instaura a possibilidade de análise da contradição dentro de uma FD, abrindo caminho para o trabalho sobre a interpelação como um ritual sempre passível de falhas, a partir do afastamento das posições radicais do assujeitamento althusseriano:

"todo discurso é o índice potencial de uma agitação nas filiações sóciohistóricas de identificação, na medida em que ele constitui ao mesmo tempo efeito dessas filiações e um trabalho (mais ou menos consciente, deliberado, construído ou não, mas de todo modo atravessado pelas determinaçõ es inconscientes) de deslocamento no seu espaço: não há identificação plenamente bem sucedida" (Pêcheux, 2002, p. 56).

Como se verá pela análise da ritualização do exorcismo da Universal, para a Análise do Discurso as marcas lingüísticas do texto só interessam enquanto pistas da historicidade própria do texto, daquilo que o faz ter um sentido em sua relação com a exterioridade. Quanto ao procedimento analítico de leitura dessas marcas, Maingueneau (1984, p. 27), ao estabelecer o primado do interdiscurso na análise das FDs, elege a relação interdiscursiva ${ }^{4}$ como fundamental, propondo um desdobramento da noção de interdiscurso em universo discursivo, campo discursivo e espaço discursivo. A primeira no-

\footnotetext{
${ }^{4}$ Em Alchimie politique du miracle, 1999, André Corten, fazendo uso de um dispositivo analítico inserido na Análise do Discurso, analisa o esquema narrativo dos testemunhos de milagre de fiéis da Igreja Universal, mostrando que estes são simples e estereotipados. A eficácia da "máquina nar rativa" da IURD é atribuída, en tre ou tros fatores, à "fagocitose do discurso medical", incorporado-recusado no discurso da cura divina. Corten propóe aqui a análise de um recorte interdiscursivo do discurso da IURD diferente do que proponho, uma vez que seu foco é a análise dos testemunhos de milagre.
}

Debates do NER, Porto Alegre, ANo 6, N. 7, P. 11-78, JAn./Jun. 2005 
ção, de pouco interesse para o analista, dada sua globalidade, refere-se ao "conjunto de formações discursivas de todos os tipos que interagem numa dada conjuntura". Serve de horizonte para construir domínios suscetíveis de serem estudados, os campos discursivos. Essa segunda noção diz respeito a "um conjunto de formações discursivas que se encontram em concorrência, se delimitam reciprocamente em uma região determinada do universo discursivo" (Maingueneau, 1984, p. 28). Pode se tratar do campo político, gramatical, etc. É no interior de um campo discursivo que se pode apreender relações de dominação em termos de operações regulares entre formações discursivas, não sendo possívelestudar um campo integralmente; deve-se então recortar um espaço discursivo, constituído de recortes discursivos que o analista isola com propósitos específicos de análise, baseados no conhecimento dos textos e em um saber específico (por exemplo, para recortar o espaço discursivo religioso devoto, que engloba o discurso jansenista e o discurso humanista devoto, Maingueneau apoiou-se na idéia defendida por certos especialistas segundo a qual o jansenismo se explicaria como uma reação contra o humanismo devoto).

Desse modo, Maingueneau $(1984,1991)$ pretende dar conta, através do primado do interdiscurso, dos diferentes planos da discursividade, ou melhor, da interdiscursividade. Seu trabalho se insere na vertente que chama de dialogismo constitutivo, termo emprestado a Bakhtin, cujos desdobramentos são analisados por J. Authier, na confrontação entre heterogeneidade constitutiva e heterogeneidade mostrada.

"No espaço discursivo, - diz Maingueneau -, o Outro não é nem um fragmento localizável, nem uma citação, nem uma entidade exterior; não é necessário que ele seja atestável por alguma ruptura visível da compacidade do discurso. Ele se encontra na raiz de um Mesmo sempre já descentrado em relação a si próprio, que não é em nenhum momento focalizável sob a figura de uma plenitude autônoma. Ele é o que sistematicamente falta num discurso e lhe permite fechar-se em um todo. Ele é esta parte do sentido que foi preciso que o discurso sacrificasse para constituir sua identidade" (Maingueneau, 1984, p. 31). 
Segundo Maingueneau, esse refinamento terminológico possibilita a análise de relaçôes entre discursos que se delimitam reciprocamente, que, segundo o autor, estão sob um processo de "tradução gen eralizada" ligada a uma interincompreensão recíproca (Maingueneau, 1991, p. 164). Tal tradução, bastante peculiar, não se dá entre línguas naturais, mas entre zonas diferentes da mesma lingua (FDs diferentes), fazendo com que "um enunciado de um arquivo pode ser lido em seu verso e seu inverso: sobre uma face ele significa seu pertencimento a seu próprio discurso, sobre a outra ele marca a distância constitutiva que o separa de um ou vários outros discursos". As regras da interincompreensão constitutiva são assim as mesmas regras que definem a identidade das FDs em delimitação recíproca, ou seja, a identidade discursiva é constituída na relação com o outro. Dentro de um espaço discursivo, "cada um (dos discursos) introduz o outro em seu fechamento traduzindo seus enunciados nas categorias do mesmo e portanto só tem relação com este outro sob a forma do 'simulacro' que dele constrói” (Maingueneau, 1984, p.12).

Interessa para Maingueneau, portanto, a análise dos diferentes planos da interdiscursividade. $\mathrm{O}$ processo de interincompreensão constitutiva é apresentado então como resultante de uma prática discursiva, num sentido um pouco diferente daquele de Foucault. Para Maingueneau, a noção de prática discursiva diz respeito aos dois aspectos da existência do discurso:

"nãodiremos que um grupo gere do exterior um discurso, mas que a instituição discursiva possui em certo nivel duas faces: uma social, outra linguageira (...). A noção de prática discursiva integra assim esses dois elementos: de uma parte o arquivo (FD), de outra o que chamaremos de comunidade discursiva, ou seja, o grupo ou as redes de grupos no interior das quais são produzidos, geridos os textos desse arquivo" (Maingueneau, 1984, p. 189-190) (minha tradução).

Desse modo, a prática discursiva determina a interincompree nsão constitutiva entre os discursos que estão em relação em um mesmo espaço discursivo nos diferentes planos da interdiscursividade. Tal relação polêmi- 
ca entre as duas FDs de um mesmo espaço discursivo, considerada assim como uma prática, se produz como efeito de relações de contradição-subordinação-desigualdade entre formações ideológicas conflitantes, materializadas na língua através das FDs que lhes correspondem. Isso é bastante visível na relação entre o discurso iurdiano e o das religiōes afro, na luta entre a afirmação e resistência da subjetividade religiosa negra e a hegemonia do cristianismo na sociedade brasileira.

\section{SOBRE O CORPUS E A ANÁLISE DO RITUAL}

Para a análise do ritual de libertação e cura da IURD, são adotados os pressupostos teóricos da Análise do Discurso, tal como definidos acima.

Procuro explicitar, a partir da análise do ritual, o funcionamento discursivo do discurso da IURD, tendo em mente a determinação exterior, a heterogeneidade de qualquer discurso, tal como está em Pêcheux (1995, 1997). O ritual de exorcismo presente nas reuniōes da igreja é interpretado como instância representativa da relação que a IURD mantém com as religiōes afro, a partir do que se pretende compreender o funcionamento discursivo no qual os saberes das religiōes afro vêm ser traduzidos nas práticas da igreja neopentecostal em questão.

Designo então a formação discursiva (FD) que determina o ritual de libertação e cura como FD1, FD iurdiana, lugar de inscrição de todas posiçóes-de-sujeito identificadas em qualquer medida com o discurso neopentecostal da IURD. Deve-se enfatizar que o objetivo aqui não é explicitar todas relações dialógicas que FD1 mantém com o interdiscurso, tal como as relaçóes com o discurso medical ${ }^{5}$ ou empresarial, por exemplo. Com base na hipótese dos antropólogos e sociólogos, restrinjo a pesquisa à análise das formas da relação conflituosa que FD1 mantém com a FD das religiōes afro, que designo por FD2. Nesse sentido, FD1 e FD2 estão em

\footnotetext{
${ }^{5}$ Lembro aqui a análise que A. Corten faz da "fagocitose" do discurso medical por parte do discurso neopentecostal da IURD (Corten, 1999).
} 
relação em um mesmo espaço discursivo, tal como definido acima. Devo, portanto, analisar a determinaçãodessa relação no funcionamentodiscursivo do ritual em questão.

Para tal, assisti a várias reuniōes da IURD em que havia ritual de exorcismo. Foram gravadas e transcritas dez reunióes assistidas em cinco igrejas de localizações diferentes ${ }^{6}$, no período de março de 2003 a janeiro de 2004. Os horários das reuniōes e localizaçôes dos templos foram obtidos através do site oficial da instituição.

Recorto o ritual de exorcismo, que preferimos chamar no seu todo como ritual de libertação e cura, não como pertencente a uma reunião específica, mas como ritual próprio do discurso da IURD como um todo. Transcritos os rituais, as seqüências discursivas foram divididas em grupos de seqüências relativos a momentos distintos do ritual, ou partes. Assim temse a invocação do Espirito Santo, a invocação do encosto, o ato de exorcismo e a confirmação da libertação. Além desse material gravado, tive acesso a jornais, revistas e ao site oficial da Igreja. Esse material serviu apenas como apoio, não sendo objeto de análise.

Os rituais foram gravados nas reuniōes de terça-feira (Sessão do Descarrego) e sexta-feira (Corrente da libertação). Lembro que nessas reuniōes, através da prática do exorcismo, os pastores da IURD pretendem libertar as pessoas da ação do mal, que então se identifica como entidade afro, no momento do interrogatório.

Desse modo, para analisar o funcionamento discursivodo ritual tomo as categorias apresentadas no quadro institucional da IURD como lugares de sujeito próprios à FD1. Julgonecessário tal procedimento uma vez que, segundo a concepção discursiva da linguagem, aquilo que se fala é determinado pelo lugar de onde se fala. Assim, tem-se o sujeito-bispo ou sujeito-pastor (ambos podem conduzir a reuniāo), sujeito-fiel, sujeito-obreiro, sujeito-enosto e sujeito-fiel desincorporado como lugares de sujeito do ritual onde podem se inscrever diferentes posiçôes-de-sujeito, tal como definidas acima.

${ }^{6}$ Visitei majoritariamente os templos dos bairros Centro, Agronomia e Chácara das Pedras. 
Com relação aos rituais das religiōes afro, tomou-se como base a observação in loco de uma dezena de rituais, a consulta à literatura antropológica e sociológica sobre essas religiōes, bem como à literatura especializada de escritores praticantes dessas religióes, além do recurso a cinco entrevistas com pais e mães-de-santo de Porto Alegre.

Sobre FD2, convém enfatizar sua pluralidade. Sob esse rótulo agrupo aqui os saberes referentes tanto à Umbanda, Batuque e Quimbanda ${ }^{7}$, tendo como núcleo comum sua natureza de religião de origem africa na e o fato de serem alvo de críticas da IURD como um todo. É claro que os saberes diferem bastante entre as denominaçôes, mas creio poder agrupá-las sob uma mesma FD, tal como os antropólogos e sociólogos estudados o fazem, chamando-as de religiō es afro, pois tal recorte permite analisar a própria redução que FD1 faz de FD2, não sendo possível dizer se o ataque da IURD é só para uma e não para outra, quando na verdade é para todas ao mesmo tempo. De qualquer forma, apesar dessa multip licidade de formas de culto decorre nte da hetero geneid ade de FD2, acredi to que, uma vez que não tenho como objetivo analisar o culto afro mas sim sua tradução em FD1, o acesso ao arquivo dessas religióes permiti rá apontar divergências quando essas se apresentarem como significativas para o objetivo da análise.

\footnotetext{
${ }^{7}$ Sem pretender ser exaustivo na descrição dessas linhas de culto afro, e fazendo uso da sis tema tização do an tropólogo Norton F. Correa (1994), direi que na Umban da "pu ra", mais sincrética das três, as entidades cultuadas são pretos-velhos, caboclos e orixás-daUmbanda; na Nação ou Batuque "puro" são cultuados apenas os orixás e que na Quimbanda ou Linha Cruzada, todas as entidades já mencionadas são cultuadas além dos exus e pomba-giras. É importante dizer que nenhum desses cultos, aqui discriminados de maneira ideal-típica, se constitui de sistemas religiosos homogêneos e puros. A "regional ização" dos cultos afro é um fator interdiscursivo importante. Em outros Estados, as designações das entidades invocadas na IURD variam segundo as linhas cultuadas (por exemplo, as entidades do Candomblé na Bahia).
}

Debates do NER, Porto Alegre, Ano 6, N. 7, P. 11-78, jan./Jun. 2005 


\section{AS FORMAS DA ILUSÃO DE REVERSIBILIDADE NA INVOCAÇÃO DO ESPÍRITO SANTO}

O funcionamento discursivo do ritual de libertação e cura é aqui analisado como "a atividade estruturante de um discurso determinado, por um falante determinado, para um interlocutor determinado, com finalidades especificas" (Orlandi, 1987, p. 125). Com isso remete-se as marcas formais dessa prática às propriedades do discurso estudado. Nesse contexto a determinação do discurso e do interlocutor são modos de estar na linguagem que configuram a historicidade do sujeito e da língua em relação à exterioridade do discurso.

O funcionamento discursivo de todo ritual de libertação e cura, a partir da inscrição do sujeito enunciador na FD que regula suas formulações, instaura diferentes posições enunciativas que se dividem entre o plano temporal e o plano divino. Através da ilusão de reversibilidad e própria ao funcionamento do discurso religioso (Orlandi, 1987), entre essas posições se estabelecem interlocuções que, regidas pela FD1 em que se inscrevem, configuram espaços de poder que atribuem um lugar específico para os fiéis, para Deus, para os encostos (que equivale a Diabo) e para o próprio bispo, que tem um papel central durante todo o ritual. Ou seja, a ritualização discursiva da enunciação dos saberes de FD1 constitui esses lugares, determinando diferentes estatutos e coerçôes às posições de sujeito aí concernidas.

Ao adotar a perspectiva interp retativa da Análise do Discurso, concebo, como Pêcheux (1997), que o "discurso é efeito de sentido entre interlocutores", ou seja, eu e tu se comple mentam em sua intera ção, de modo que o sentido que dão às suas palavras é sempre mediado por formações imaginárias (Pêcheux, 1997) que fazem um do outro e do objeto do discurso. Na verdade, a consti tuição do sujeito e a consti tuição do sentido se dão em um mesmo momento no discurso. Ao longo da análise, será privil egiada a consti tuição dialóg ica do discur so da FD1 em relação à FD2, examin ando a imagem que o discur so de FD1 faz do discurso de FD2. 
Assim, observando as diferentes interlocuções que ocorrem durante o ritual de libertação e cura, a análise do corpus apresenta as seguintes interlocuções :
a) Bispo $\rightarrow$ Fiel
b) Fiel $\rightarrow$ Deus
c) Bispo $\rightarrow$ Deus
d) Fiel $\rightarrow$ Encosto
e) Bispo $(\leftarrow) \rightarrow$ Encosto

Enfatizo que o sentido unívoco das flechas representa a nãoreversibilidade na tomada da palavra. Assim, em a) o fiel nunca se dirige ao bispo; se isso ocorre é apenas para responder perguntas do tipo sim ou não?, ou quem tem fé?, quem crê?, etc. Além disso, a não-reversibilidade entre fiel e bispo advém não só do direito à palavra, mas à qualidade da palavra, sendo a palavra do bispo associada ao divino.

Tomando o início do ritual, em que há a invocação do Espírito Santo, vê-se que a interlocução Bispo $\rightarrow$ Fiel é sempre a interlocução que abre a cerimônia, em ambas as reuniôes em que ocorre. O sujeito-bispo começa com uma saudação simples como bom dia lboa noitel boa tarde pessoal, enquanto caminha com disposição até o centro do altar com um microfone em mãos. A função fática dessa saudação assegura o reconhecimento do locutor como bispo ou pastor, representante e porta-voz do dizer divino.

No funcionamento discursivo que rege essa interlocução, observa-se que o dizer do sujeito-bispo possui diversos poderes performativos: o sujeito-bispo é ao mesmo tempo o árbitro das interlocuções, o controlador dos

\footnotetext{
${ }^{8}$ Nesse trabalho não serão abordadas todas interlocuções do ritual. Serão examinadas somente a interlocução Bispo $\rightarrow$ Fiel, no início do ritual e antes da invocação do Encosto; a interlocução Bispo $\rightarrow$ Encosto, em que há a interpelação da alteridade; a interlocução Bispo $\longleftrightarrow$ Encosto, no momento do exorcismo; e, finalmente, a interlocução Bispo $\longleftrightarrow$ Fiel, que encerra o ritual de libertação e cura da IURD. Para a análise de todas interlocuçōes, ver Ribeiro (2005).
}

Debates do NER, Porto Alegre, Ano 6, N. 7, P. 11-78, jan./Jun. 2005 
corpos dos sujeitos-fiéis e seu dizer é o lugar de constituição de diferentes imagens colocadas em relação durante toda a prática ritual, materializadas na determinação discursiva de suas posições. Predominante durante toda o ritual de libertação e cura, o dizer do sujeito-bispo se diz (e assim é tido pelos sujeitos-fiéis identificados com FD1) guiado o tempo todo pela intervenção (ilusão de reversibilidade) do poder do Espírito Santo. Segundo as características que apresento do pentecostalismo, a presença do sagrado no corpo dos pastores e bispos é um tema próprio à intertextualidade interna de FD1, à sua leitura singular das Escrituras Sagradas.

Como se tem apresentado no estudo do discurso religioso, o maior poder do locutor advém de uma assimetria constitutiva entre ele e seu interlocutor, o fiel (Orlandi, 1987). Isso quer dizer que não só não falam (não podem falar) as mesmas coisas, como o modo como falam é diferente, o que atribui diferentes níveis de poder performativo 9 às figuras enunciativas constituídas na enunciação. Assim, na relação de forças que subjaz essa interlocução, a voz do locutor é associada à voz de Deus, e a imagem que os sujeitos-fiéis fazem do sujeito-bispo é a de representante da palavra divina, guiado pela intervenção do Espírito Santo. É preciso esclarecer sempre que tal poder de levar a cabo essas atribuiçóes (invocar a divindade, ditar as normas de contato com a divindade) não advém do bispo enquanto sujeito psicológico capaz de estabelecer estratégias retóricas, mas que, antes, tal poder se instaura na própria enunciação da afirmação desse poder; ato que, partindo de uma FD na sua relação com o interdiscurso, produz o bispo para os fiéis enquanto representante da voz divina e, portanto, dotado de certa legitimidade - con tra o encosto.

\footnotetext{
${ }^{9}$ Remeto aqui às reflexôes do filósofo J. L. Austin. Ao observar a linguagem ordinária, Austin constata um erro na prática de alguns filósofos: a crença na idéia de que a linguagem representa o mundo por uma simetria lógica, sendo uma sentença verdadeira ou falsa na sua relação com o mundo. Austin revoluciona a filosofia analítica ao conceber a linguagem enquanto ação sobre o mundo, prática, colocando que as circunstâncias do proferimento de uma sentença são determinantes para o sucesso ou insucesso da ação que se pretende praticar ao dizer (Cf. Austin, 1990). Aqui a ritualização da linguagem é tomada como uma condição de sucesso do agir religioso sobre o mundo.
} 
No início do ritual de libertação e cura, geralmente, o sujeito-bispo começará a cantar uma música, que é automaticamente acompanhada por um órgão eletrônico situado atrás do altar. São músicas que clamam a presença da divindade, glorificam seu poder, geralmente enfatizando o contato com Deus através das mãos (parte do corpo muito valorizada nos rituais da IURD). Diferentemente das outras músicas que se reproduzem durante o resto do ritual (geralmente alegres), essas iniciais têm um caráter mais solene, respeitoso.

Na invocação do Espírito Santo, o sujeito-bispo é o lugar de dizer que dá forma à possibilidade do contato dos sujeitos-fiéis com o sagrado. É o lugar de autoridade que repete, incorpora um etos próprio aos representantes dessa designação neopentecostal; tendo como figura central o bispo Edir Macedo, a preparação dos novos pastores e mesmo obreiros promove uma ritualização do carisma e da afirmação de autoridade.

Ao contrário de uma ultrapassagem sem restriçóes ao fiel do plano temporal ao plano divino, é a posição enunciativa sujeito-bispo que determina a forma de contato com a divindade: as palavras que devem ser usadas e o modo corporal de enunciá-las. Essa ultrapassagem do sujeito-fiel, seu direito a falar com a divindade previsto em FD1, é determinada por condiçôes enunciadas no dizer do sujeito-bispo, sem a observação das quais o que se dá como o ato de linguagem invocar a divindade não se realiza efetivamente.

Apresento a seguinte seqüência discursiva da interlocução Bispo $\rightarrow$ Fiel como um exemplo da injunção ao contato com a divindade no início do ritual:

Sdr1: Peça a Deus isso, peça a Ele agora, diga: Jesus, eu vim aqui, diga: pai das luzes, eu vim aqui pra vencer esse mal, eu não vou poder sair do mesmo jeito que $e u$ entrei/da mesma forma que eu entrei, eu quero sair liberto, eu quero sair sem essa maldição/sem esse encosto, esse encosto que há tantos anos vem tirando a minha paz, que há tantos anos vem me perturbando, vem tirando o meu sossego.

Debates do NER, Porto Alegre, ano 6, N. 7, P. 11-78, jan./Jun. 2005 
Sdr2: Levante as mãos. Peça agora ao pai maior/das luzes pra Ele colocar o fogo de Deus nas tuas mãos, diga: Meu Deus, coloca fogo. Meu Deus, coloca fogo nas minhas mãos, porque eu vou determinar nesta noite a minha libertação, eu vou determinar que a partir de hoje $e u$ vou ser liberto, a partir de hoje eu vou ser livre.

De pé, com as mãos levantadas e de olhos fechados, os sujeitos-fiéis repetem o dizer do sujeito-bispo, ou seja, no dizer do sujeito-bispo (cuja voz se associa a de Deus) está o que os sujeitos-fiéis devem dizer a Deus. $\mathrm{O}$ ato de invocar a divindade se realiza, portanto, obedecendo-se a uma ritualização lingüístico-discursiva própria ao funcionamento discursivo de FD1. Desde sempre é um ato que tem como condição de existência uma ponte entre duas lógicas religiosas, de modo que pode ser sempre tomado tanto como uma verdade incontestável quanto como a pior das calúnias.

Observa-se assim que a mistificação da autoridade do dizer do sujeitobispo está marcada aqui pela divisão do locutor em dois enunciadores: eubispo e eu-fiel. Se se pode dizer que no momento do diálogo do exorcismo o eu na boca do sujeito-fiel é outro que não ele, nesse momento o eu na boca do sujeito-bispo é um lugar de sujeito-fiel próprio do imaginário iurdiano, tendo como contraparte necessária à condição de homem a influência e o jugo do encosto, da verdade e da mentira do outro discurso.

O dizer do sujeito-bispo serve de lugar para a identificação do sujeitofiel, sempre capaz de um trabalho do sentido sobre o sentido. De todo modo é o reconhecimento de uma posição de autoridade que se marca na mediação do sujeito-bispo no contato entre o sujeito-fiel e a divindade, cabendo à posição do sujeito-fiel a reprodução de uma paráfrase (reprodução do dizer do sujeito-bispo) que o identifica enquanto sujeito-fiel buscando estabelecer contato com o Espírito Santo. Assim, essa forma de ilusão de reversibilidade, dado o entrecruzamento de vozes que a constitui, se sustenta num aparente apagamento da posição enunciativa do sujeito-bispo, que faz falar o fiel em sua voz, mas que, ao contrário, estabelece as condições de possibilidade da interlocução Fiel $\rightarrow$ Deus.

Com relação ao estatuto que este eu-fiel tem na forma ditada pelo eu-

Debates do NER, Porto Alegre, ano 6, N. 7, P. 11-78, JAn./Jun. 2005 
bispo, observamos que o ato de linguagem invocar a divindade está sustentado em uma memória: a promessa divina da prosperidade, um dos temaschave da intertextualidade bíblica de FD1. É com base nesse traço de memória sustentado na leitura das Escrituras Sagradas que essa promessa abrange todos aspectos da vida do fiel, no sentido em que ter prosperidade, ser um vencedor, implica não ter nenhum tipo de problema. É uma interpretação que remete ao fundamento da Teologia da Prosperidade, tão difundida pelo neopentecostalismo. Assim, através da identificação do sujeito-fiel à imagem de fiel produzida no dizer do sujeito-bispo, todos têm o direito de cobrar de Deus essa prosperidade: "eu vim aqui para vencer". No livro "Orixás, Caboclos e Guias: deuses ou demônios", Edir Macedo apresenta essa cobrança como primeira atitude a ser tomada pelo fiel na luta contra satanás: "Você deve se apropriar de todos os seus direitos: cobre de Deus aquilo que Ele mesmo prometeu. Viva uma vida vitoriosa e abundante; nunca aceite a derrota ou a desgraça" (Macedo, 2002, p. 154).

$\mathrm{Na}$ divisão do locutor em diferentes posicionamentos tem-se a condição mesma do fazer sentido. Aqui, para obter a graça, a libertação, se faz necessário recusar um eu com o qual ainda vai se dialogar muito, depois refutar e silenciar, com apoio na possibilidade de enunciar um $e u$ do qual o sujeito-bispo conta a história, qualifica. Esse outro eu, cujas verdades devem ser ditas mentiras no confronto com o Espírito Santo, deve submeter-se primeiramente a um interrogatório, quando já não é mais eu, mas outro (possessão), dominado, e depois silenciar. Antes, porém, sua presença no espaço do Templo, de certo modo aguardada, marca a resistência ao ideal (outro eu) com gritos, urros e corpos contorcidos.

\section{A INTERPELAÇÃO DA ALTERIDADE: SIMULACRO E POSSESSÃO}

A segunda parte do ritual de libertação e cura, que denomino invocação do Encosto, se desenvolve tendo como pano de fundo uma melodia grave e sinistra. Aliada ao tom de voz do sujeito-bispo e dos sujeitos-pasto-

Debates do NER, Porto Alegre, Ano 6, N. 7, P. 11-78, jan./Jun. 2005 
res que eventualmente tomam a palavra, essa melodia contribui para a instauração de uma atmosfera de pesar, de batalha, cuja duração é de aproximadamente vinte ou trinta minutos.

Uma vez invocada a divindade do Bem, a confirmação da sua presença só se dará a partir da confirmação da presença de seu outro, pois segundo as regras discursivas de FD1, a manifestação dos Encostos é conseqüência da presença do Espírito Santo, que os força a manifestarem-se. Os gritos que surgem ao longo da invocação do Encosto somam-se também à atmosfera soturna, "pesada" do Templo, que durante a invocação do Encosto permanece semi-iluminado.

Durante esse segundo momento do ritual, a possessão, resultado de algo que se exterioriza, é a materialidade do milagre (ultrapassagem) tanto da presença (interior) de Deus, quanto (agora exterior) do Encosto. O corpo do sujeito-fiel é assim um espaço de luta aberto à intervenção do Bem e do Mal - um receptáculo do divino.

No decorrer do ritual, na luta entre tais presenças, o exorcismo será a materialidade do poder de Deus (Bem) sobre o Encosto (Mal), na expulsão temporária dessa alteridade que constitui a unidade do sujeito do discurso.

O momento da invocação do encosto tem nas interlocuções Bispo $\rightarrow$ Fiel (a alteridade do sujeito-fiel é interpelada indiretamente) e Bispo $\rightarrow$ Encosto (a alteridade é interpelada diretamente) dois pontos chave para a análise da determinação da exterioridade na produção dos sentidos.

A INTERLOCUÇÃo Bispo $\rightarrow$ Fiel

Ainda sem encostos incorporados no espaço do Templo, pois ainda não foram invocados, o sujeito-bispo se dirige ao sujeito-fiel primeiramente enunciando a corporalidade própria à invocação do encosto:

Sdr3: Põe as mãos na cabeça agora. Feche os olhos, gente, coloque as mãos sobre a sua própria cabeça. Faça uma leve pressão sobre a sua cabeça, feche seus olhos, não abra os olhos agora.

Debates do NER, Porto Alegre, ano 6, N. 7, p. 11-78, JAn./Jun. 2005 
A seqüência de imperativos evidencia na linguagem o poder do sujeito-bispo sobre o corpo do sujeito-fiel. Aqui as formas de inclusão do interlocutor são similares às da invocação do Espírito Santo. Durante todo ritual o sujeito-bispo interpela os sujeitos-fiéis diretamente através da forma você que $X$, interpelação responsável ao mesmo tempo pela construção imaginária de um sujeito-fiel necessitado de salvação e pela produção da identificação dos sujeitos com essa imagem, através do reconhecimento ideológico (é assim mesmo, sou eu.) (Pêcheux, 1995) que recruta os sujeitos a preencherem um lugar no conjunto do dizível de uma FD. Uma diferença, porém, marca a interpelação do já-sujeito-fiel nessa parte do ritual, como se pode observar nas seguintes seqüências:

Sdr4: Em nome do senhor Jesus, põe a mão no seu coração, feche seus olhos, põe a mão no seu coração agora, isso mesmo. Você que já manifestou um encosto, vem aqui na frente. Você que ouve vozes, vê vultos, isso, vem aqui na frente. Você que tem um problema antigo, vem aqui diante do altar, sai daí agora, vem aqui na frente. Você que vestiu roupa branca na casa de encosto, Batuque. Você que vestiu roupa branca na casa de religião, vem aqui diante do altar agora e coloca as mãos no seu coração.

Sdr5: Você ouve vozes, vê vultos, tem medo, depressão, insônia e tem um vício que não consegue abandonar. Você é uma pessoa que tem dupla personalidade. Uma hora tá calmo, tranqüilo, consciente. Outra hora você perde, como diz o outro, a estribeira. Você que é uma pessoa que é vítima dos Encostos, vem aqui na frente. Ou você que serviu os Encostos, colocou roupa branca, uso pó de pemba, fez bori, ebó, você tá entendendo o que eu to falando. Você que consultou com a cartomante, você se consultou e foi jogar búzios, vem aqui na frente, por favor. Você já participou de gira... de gira, na casa de religiāo, cê já foi na casa de religião, na macumba, vem aqui na frente. "Ah, mas eu não botei roupa!”, mas botou o pé lá dentro! Bastou botar o pé lá, é delito.

$\mathrm{Na}$ interpelação através da construção relativa você que $X$, a identificação do sujeito-fiel é determinada pela relação entre os efeitos de préconstruído, o "sempre-já-aî" que "fornece impõe a realidade e seu sentido" sob a forma da verdade (Pêcheux, 1995, p. 164) e o discurso-transverso que 
joga na articulação de pré-construídos de FD2 (veste-se roupa branca na casa de religião, há encostos e há pessoas com uma singular dupla personalidade, etc.) traduzindo-os em objeto de deprecação na sintagmatização do in tradiscurso de FD1, produzindo a interpretação - sempre passível de falha (Mas eu não botei roupa!) - entre isso existe, eu fiz isso, isso é condenável (é delito) $=$ eu preciso de libertação.

Assim, durante a invocação do Encosto, sujeitos que (antes) se identifica(va)m com FD2 são diretamente interpelados para produzir em seu dizer (e fazer) o simulacro de FD2 (a re-leitura de suas memórias), na possessão (resposta à invocação de Deus e do Encosto) e no exorcismo (submissão ao poder do Bem, à verdade). Nessa interlocução Bispo $\rightarrow$ Fiel, portanto, já é possível identificar a heterogeneidade de FD1 na inscrição de saberes de FD2 em seu discurso, e a conseqüente dualidade do sujeito-fiel, tema de todas interlocuçóes. $\mathrm{O}$ sujeito-fiel que se identifica com tal interpelação, no momento em que reconhece e condena a alteridade que o constitui, encarna materialmente a divisão que se impõe ao homem no discurso religioso: a de ser pecador (= ter (tido) alguma relação com o mal) e de necessitar da salvação (= se identificar com o Espírito Santo).

Em termos de formações imaginárias, para o sujeito-fiel que se identifica com as interpelaçôes acima, o sujeito-bispo tem legitimidade de invocar um seu (do fiel) outro que deve ser expulso, ainda que a memória desse outro deva permanecer, agora traduzida, como condição de haver sujeitosfiéis. Isso significa que os sujeitos do ritual de libertação e cura se constituem, através do funcionamento do discurso-transverso, na relação in terdiscursiva entre FD1 e FD2, através da produção de u ma tradução simulacro do discurso do outro.

\section{A INTERLOCUÇÃo Bispo $\rightarrow$ ENCOSTO}

Com base no funcio namento da interp elação do sujeito-fiel, no compartilhamento de pré-construídos, percebe-se que FD1 e FD2 estão em relação intendiscursiva em um mesmo espaço discursivo, ou seja,os enundiadosde 
FD1 estão em relação dialógica com os enunciados de FD2. À luz das reflexões de Bakhtin, precursor dos estudos sobre o princípio dialógico de todo enundado, pode-se dizer que os enunđaados atualizados no ritual de libertação e cura da IURD, assim como todo signo ideológico vivo, têm, "como Jano, duas faces. Toda critica viva pode tornar-se elogio, toda verdade viva não pode deixar de parecerparaalguns a maiordas mentiras" (Bakhtin, 2002, p.47). É nesse sentido que o ritual de libertação e cura pode ser interpretado como uma resposta ao discurso de FD2, uma resposta que toma a forma de uma acusação.

De fato, há vasta literatura antropológica e sociológica sobre a relação entre IURD e religióes afro-brasileiras, como apresentei acima. Na verdade, inclusive a "semelhança" dos rituais da IURD com os rituais afro é reconhecida pelo próprio "fundador" da Igreja: "Se uma pessoa chegar à Igreja no momento em que as pessoas estão sendo libertas, poderá pensar que estão em um centro de macumba, e parece mesmo" (Macedo, 2002, p. 135).

Creio que a contribuição própria de uma análise discursivapara o campo da antropologia pode servir como parte relevante do material etnológico, bastante significativa para o conhecimento da cultura, na medida em que faz remissão a fatores histórico-sócio-culturais do funcionamento dos textos produzidos por comunidades discursivas em relação. Nesse sentido, sem pretender equivalên cia de termos ou objetos e tomando a perspectiva discursiva, creio que a "inversão simbólica" ou "ponte" existente entre a IURD e as religiōes afro deve ser interpretada como fruto de uma relação constitutiva entre FDs em um espaço discursivo.

Até aqui se definiu essa relação gen ericamente como uma "tradução", uma construção de um simulacro. Por simulacro entende-se uma espécie de imagem refletida num "espelho torto", algo diferente da cópia, uma "imagem sem semelhança"10 (Deleuze, 1974, p. 263). Deleuze, ao revisitar as noções

\footnotetext{
${ }^{10} \mathrm{O}$ antropólogo Ari Oro propõe uma bela metáfora: "a IURD e as religiōes afro-brasileiras estão em constante relação dialética de antagonismo e de aproximação, tal como dois espelhos que se refletem mutuamente, e cujos passos tomados por um são iluminados pelo brilho proveniente do outro" (Oro, 2004). Acrescen taria que a reflexão, en quanto simulacro, é sempre de uma imagem sem semelhança.
}

Debates do NER, Porto Alegre, Ano 6, N. 7, P. 11-78, jan./Jun. 2005 
de cópia e de simulacro na filosofia platônica, toma o catolicismo, tão inspirado nessa filosofia, para mostrar como o próprio homem pode ser pensado como um simulacro de Deus: "Deus fez o homem à sua imagem e semelhança, mas, pelo pecado o homem perdeu a semelhança, embora conservasse a imagem. Tornamo-nos simulacros..." (Deleuze, 1974). Donde o "caráter demoníaco" do simulacro advir do fato de ele ser "construído sobre uma disparidade, sobre uma diferença, ele interioriza uma dissimilitute". Tal é a razão pela qual deve-se distinguir a cópia do simulacro, pois não se pode definir o simulacro nem mesmo com relação ao modelo que se impõe às cópias: "se o simulacro tem ainda um modelo, trata-se de um outro modelo, um modelo do Outro, de onde decorre uma dessemelhança interiorizada" (Deleuze, 1974). Tais reflexôes parecem de extrema importância para a compreensão da tradução do discurso de FD2 por FD1. Nesse processo ocorre algo como que uma interiorização de um outro modelo que instaura a dessemelhança dentro do mesmo, como se FD1 "traduzisse" FD2 em algo diferente dela mesma, conservando-lhe uma certa imagem, a qual faz parte do que deve ser dito, mais propriamente, refutado em FD1.

Depois da invocação do Espírito Santo, a partir do momento em que o sujeito-bispo se dirigeao encosto, a música, outrora calmae harmoniosa, ganha traços graves e sinistros. O Templofica semi-iluminado. Também o tom da voz do sujeito-bispo se torna alterado, mais agressivo, e o sujeito-bispo começa a andar de um lado para o outro do altar, às vezes vociferando contra o encosto. Do mesmomodo como ocorre na invocação do Espírito Santo, aquia apelação objetivante cria o referente instanciando-o como interlocutor.

Com relação aos sujeitos-fiéis, todos com as mãos na cabeça e de olhos fechados, depois de serem interpelados diretamente, o sujeito-bispo agora os inter pela indiretamente, na invocação que faz do Encosto, como exemplificamos com as seguintes sdrs.

Sdr6: A pomba gira que está com esta mulher e que só traz homem casado pro caminho dela! Vamo lá, Maria Bonita! Maria Padilha! A pomba gira Rainha, que quer levar ela à prostituição, manifesta, manifesta agora! Você ganhou um trabalho pago com cachaça, com uísque, o espírito que vem 
atuando nesta pessoa há anos, há várias luas, como vocêfala, ENCOSTO! Sai, sai, sai! da matéria dessa pessoa, você que vem fazendo a matéria dela ficar doente, vem aqui agora o espírito chamado Malandrinho, chamado Jé Pelintra, vamos, vai saindo daí agora, você que usa o número sete, você chamado Sete-Facadas, MANIFESTA AI!

Sdr7: Vamos, Exu-caveira, sai desse corpo agora, sai daí Maria Molambo, Maria Padilha! pomba-gira que ganhou champanhe, que ganhou rosas, que ganhou cetim, você que ganhou trabalho pra destruir o casamento, da cunhada, da sogra, você foi pago pela amante do marido, pra fazer essa mulher secar, definhar, e tá botando nela o câncer! Sai daí espírito que tá colocando uma doença na filha, no filho, que tá levando familiares pras drogas! O ZéPelintra, o ENCOSTO que está causando uma destruição total! Você passou como um furacão pela casa dessa pessoa, e vem acabando com tudo! MANIFESTA AÍ, ENCOSTO!

Sdr8: Isso! Manifesta! Dá o teu grito! Dá o teu grito, DÁ O TEU GRITO! Porque essa pessoa veio aqui hoje para ser livre. E o seu trono vai ser quebrado agora. Vamos lá, Orixá! MANIFESTA AÍ! O caboclo que ta aí, o Oxalá que ta aí, o Tupinambá, MANIFESTA, VAMOS! É UMA ORDEM!

Nesse momento do ritual o sujeito-bispo se dirige para algo que está escondido no corpo do sujeito-fiel. Ele interpela a alteridade sua alteridade. A partir do exame das seqüências, o funcionamento discursivo da construção do simulacro da alteridade de FD1 pode ser analisado através dos processos de designação e de adjetivação do outro.

\section{a) construção do simulacro no processo de designaçāo.}

$\mathrm{Na}$ análise das formas da invocação do Encosto, os processos de designação ${ }^{11}$ se apresentam como pontos-chave da compreensão da tradução de

\footnotetext{
${ }^{11}$ Por processos de designação entendemos, como está em Guimarães (1995), relações de referência instáveis, produzidas pelo cruzamento de diferentes posições de sujeito.
}

Debates do NER, Porto Alegre, ano 6, N. 7, P. 11-78, jan./Jun. 2005 
FD2 por FD1, constituindo vias de acesso privilegiadas ao dialogismo constitutivo.

Assim como na interlocução Bispo $\rightarrow$ Deus, aqui o discurso cria seu referente divino, no processo de reificação do símbolo (Reboul, 1980), interpelando-o diretamente através das formas Você que $X$, O/A Y que $X$ e através de vocativos. Tomando os vocativos como lugares de designação, buscamos explicitar a família parafrástica do referente Encosto, tema chave de FD1 e intervalar entre FD1 e FD2.

A partir da ilusão de ultrapassagem entre o plano temporal e divino, o sujeito-bispo invoca o seu outro (o Diabo/o Mal) para exercer seu poder maior (de Deus) sobre ele. A presença desse Outro, het erogênea, multifacetada em si mesma, dada a miríade de representações existentes em FD2 e traduzidas em FD1, assume o lugar do um, do outro lado da dicotomia cristã: o Diabo. Tal "redução" do referente Encosto se dá através da tradução do outro (FD2), da construção de seu simulacro pelo modo como interpretam a realidade os sujeitos inscritos em FD1.

$\mathrm{Na}$ análise do discurso de FD1, a designação Encosto é um referente genérico equivalente a uma forma do Diabo, com o mesmo sentido das palavras que outras religiões cristãs utilizam para referir o Mal, a contraparte de Deus (Bem). Por terem uma intertextualidade interna semelhante (as Escrituras Sagradas), essas religiōes incorporam tal visão dicotômica.

Porém, o Diabo da IURD é uno e múltiplo ao mesmo tempo, o que não é senão resultado da relação entre as FDs em questão. Dentro da designação genérica Encosto, designações referindo as entidades das religiōes afrobrasileiras (FD2) se apresentam como outras formas do mesmo.

A respeito da utilização do vocabulário das religiōes afro pela IURD, o antropólogo Ari Pedro Oro (2004) diz que

"Encosto", "pai-de-encosto", "ex-pais-de-encosto", são termos incorporados há pouco tempo na IURD, juntamente com a implantação das "sessões de descarrego". "Encosto" é um termo utilizado no espiritismo para se referir aos espíritos obsessores de "desencarnados" que se recusam a abandonar este mundo.Para tanto, necessitada energia dos vivos. A umbanda também assume esta concepção, mas além disso acrescenta a concepção do campo afro, segundo

Debates do NER, Porto Alegre, ano 6, N. 7, p. 11-78, Jan./Jun. 2005 
o qual o encosto é associado ao "egun", espírito de um morto que sentindose só procura levar consigo outras pessoas. Tudo indica que a IURD incorpora os dois sentidos mencionados do termo "encosto"12.

A partir disto, se pode dizer que o que designo por FD2 é um conjunto de relaçóes bastan te complexas e heterogêneas que englobariam de "linhas" diferentes das religiōes afro (Umbanda, Nação, Quimbanda ${ }^{13}$ ) até elementos do espiritismo kardecista. Um espaço de relações múltiplo, extremamente heterogêneo, mas que se torna uno na tradução de FD1.

Diz-se que se torna (aparentemente) uno porque em FD1, na interlocução Bispo $\rightarrow$ Encosto, tanto são interpelados Exus e pomba-giras quanto orixás e espíritos de pessoas desencarnadas, todos submetidos ao limite da dicotomia Bem/Mal. A transformação de sentido que se observa nos processos de designação do discurso de FD1 são a forma do simulacro que FD1 cria de FD2 na redução da diversidade das entidades ao Mal.

Um primeiro deslizamento, segundo a observação de Oro, seria o fato de que em FD2 (especificamente na umbanda) Encosto refira tanto eguns e espíritos desencarnados ao mesmo tempo, sentidos também assumidos por FD1. Entretanto, além desses dois sentidos, em FD1 Encosto refere também toda e qualquer entidade afro como uma diferente manifestação do Diabo cristão, o que diferencia sobremaneira o modo como essa palavra significa nas diferentes FDs. Ou seja, no simulacro que FD1 faz de seu outro, um

\footnotetext{
${ }^{12}$ Mesa Redonda intitulada $O$ "Neopentecostalismo Macumbeiro", um estudo acerca do embate entre a Igreja Universal e as Religiōes Afro-brasileiras apresentada no $24^{\circ}$ congresso da ABA. Nota da p. 22.

${ }^{13}$ Sem pretender ser exaustivo na descrição dessas linhas de culto afro, e fazendo uso da sistematização do antropólogo Norton F. Correa (1994), diremos que na Umbanda "pura", mais sincrética das três, as entidades cultuadas são pretos-velhos, cabodos e orixás-da-Umbanda; na Nação ou Batuque "puro" são cul tuados apenas os orixás e que na Quimbanda ou Linha Cruzada, todas as entidades já mencionadas são cultuadas além dos exus e pomba-giras. É importante dizer que nenhum desses cultos, aqui discriminados de maneira ideal-típica, se constitui de sistemas religiosos homogêneos e puros. A "regionalização" dos aultos afro é um fator interdiscursivo importante. Em outros Estados, as designaçōes das entidades invocadas na IURD variamsegundo as linhascultuadas(por exemplo, as entidades do Candombléna Bahia).
} 
sentido uno é imposto à diversidade de sentidos de FD2 - essa diversidade de sentidos é silenciada, em uma relação de metáfora (Pêcheux, 1995) que podemos esquematizar no quadro seguinte:

\begin{tabular}{|c|c|c|}
\hline \multicolumn{2}{|c|}{ FD2 } & FD1 \\
\hline \multicolumn{3}{|c|}{ TRADUÇĀO - Efeito metafórico (agente:FDI) $\rightarrow$} \\
\hline exus & $\begin{array}{c}\text { Tranca-Tudo } \\
\text { Exu-caveira } \\
\text { Zé-Pelintra }\end{array}$ & \multirow{5}{*}{ Encostos = Diabo, Mal } \\
\hline pomba-giras & $\begin{array}{l}\text { Maria Bonita } \\
\text { Maria Padilha }\end{array}$ & \\
\hline caboclos & Tupinambá & \\
\hline preto-velhos & Pai Joaquim & \\
\hline orixás & Oxalá & \\
\hline
\end{tabular}

Lembro, com Silveira $(2004)^{14}$, que "uma designação produz determinados efeitos de sentidos no interior de uma FD e outros no interior de outra FD", o que explica o fato do sujeito inscrito na prática discursiva de FD 1 atribuir um sentido diferenteàs palavras que utilizava quando se inscrevia em FD2, quando as diferentesdesignações de FD2, por referirem aquilo que seu posicionamento determinava, admitia a pluralidade dos sentidos própria de seu discurso. Reafirmo assim a produção de sentidos diferenciados das designações como efeitos de contradição-subordinação-desigualdade entre formaçôes ideológicas em conflito em determinada conjuntura sócio-histórica, em sua materialização nas diferentes FDs em questão. Em outras palavras, a heterogeneidade como condição para a prática religiosa.

${ }^{14}$ Tese de doutor ado em análise de discurso: "Imaginário sobre o gaúcho no discur so literár io".

Debates do NER, Porto Alegre, ano 6, N. 7, p. 11-78, JAn./Jun. 2005 
Quando digo pluralidade me referiro ao universo mítico de FD2, que apresenta uma rica cosmogonia em que cada entidade tem suas particularidades, tanto de personalidade (bem como história, origem e relação com as outras entidades) quanto de culto (comidas, roupas e pontos ${ }^{15}$ ). Considerando que tanto as entidades como suas próprias particularidades podem variar de uma casa de culto afro para outra, para afirmar a tradução que faz FD1 fez-se uso das sistematizaçôes de antropólogos como Ari Oro (1994), Patrícia Birman (1985) e Norton Figueiredo Correa (1994), bem como de conversas e entrevistas com praticantes das religiões afro.

Silenciando (para se constituir) uma pluralidade de sentidos, o ritual de libertação e cura, ao mesmo tempo em que refuta alguns saberes (préconstruídos) de FD2 (tudo o que "subjaz, vem junto" com a designação caboclo, por exemplo), legitima outros (a própria existência de um caboclo e a possibilidade dele incorporar). Tal é o resultado da interincompreensão que reproduza polêmica entre as discursividades de FD1 e FD2 em suas práticas.

Desse modo, percebe-se que o deslizamento de sentido produzido pela tradução é o de que as designações das entidades afro (tal como significam em FD2), inclusive as da Umbanda dita pura (Oxalá, por exemplo), são todas agrupadas dentro da designação genérica Encostos e significam, em FD1, a fonte ou a representação do Mal.

Um ponto chave que pode demonstrar a expressiva heterogeneidade de FD2 e assim enfatizar o silenciamento que produz FD1 é a designação Exu. Para sujeitos de FD2 que se identificam com o sincretismo religióes afro - Igreja Católica, Exu adquire um sentido simétrico ao do Diabo cristão. Já para sujeitos que se posicionam contra essa resultante do sincretismo, o Exu "não é bem nem mau, é apenas justo. Os verdadeiros Exus estão no compromisso de uma tarefa, estando acima dos conceitos do Bem e do Mal, mas ligados aos conceitos de justiça e sua execução" ${ }^{16}$.

\footnotetext{
${ }^{15}$ Os pontos são rituais de invocação da entidade. Toca-se o tambor e canta-se um determinado ponto para invocar ou despachar determinada entidade. Podemos dizer que estão entre as condições de realização/eficácia da invocação das entidades.

${ }^{16}$ Liçôes Básicas de Umbanda, F. Rivas Neto, 1991.
} 
Tal não é o efeito de sentido produzido durante o ritual de libertação e cura na invocação do Encosto. Para os sujeitos inscritos nessa prática (bispos, pastores, obreiros e fiéis) Exu é mais uma forma do falso, do outro, o que constitui a materialidade do silenciamento de sentidos de FD2 no processo de designação do interlocutor interpelado ${ }^{17}$.

Como exemplo da pluralidade de posicionamentos com relação a essas designações, a citação que apresento acima, de um sujeito que recusa a "demonização" do Exu resultante do sincretismo, é de alguém que se assume Mestre de Iniciação de Umbanda pura. Prossegue o umbandista:

"Também não dissemos que o Exu Caveira é um "santo", que só faz o bem. Como dissemos, Exu - e nisso se inclui, obviamente, o Exu Caveira, - está acima dos conceitos do Bem e do Mal, ligando-se rígida e inflexivelmente aos conceitos de justiça e sua execução, sob as ordens de cima. (...) Assim, não há necessidade de preceituar oferendas aos Exus do campo do pó, no cemitério. (...) Nos cemitérios só têm aceite trabalhos de magia negra, e é óbvio que não com o Exu Caveira...” (Neto, 1991, p. 168).

Parece, então, que Exu e pomba-gina são designações cuja instabilidade referencial dentro do universo abrangente e heterogêneode FD2, decorrente do sincretismo, é um fator de grande importânciapara eficácia do discurso de FD1 e, conseqüentemente, do ritual de libertação e cura da IURD.

Tal instabilidade, convém ressaltar, só existe na consideração que o analistafaz do interdiscurso, nunca na atualizaçáo do discurso(intradiscurso), pois aí a identificação (interpretação) do sujeito aparece como única e verdadeira. Daí a importância da análise da paráfrase e da polissemia como vias de acesso à constituição/formulação do discurso.

Através do processo de designação da alteridade que acabo de descre-

\footnotetext{
${ }^{17}$ Silenciamento só admitido pela força das formaçōes imaginárias, que produz a legitimidade do outro (bispo) no confronto com a imagem que esse faz de mim mesmo (exu) e, em última instancia, com aquela que eu próprio faço do que sou. Quando um negro norte-americano interpela seu amigo por nigger, o efeito é diferente de quando é assim chamado por um branco.
}

Debates do NER, Porto Alegre, ANo 6, N. 7, P. 11-78, JAn./Jun. 2005 
ver, fica claro que assumir a subjetividade de "cavalo" de Exu significa reconhecer, para sujeitos identificados em qualquer medida com saberes cristãos, um posicionamento marginal e condenável. Novamente, tal é um traço da luta entre a afirmação e resistência da subjetividade religiosa negra e a hegemonia do cristianismo (mesmo sincrético) no Brasil. Um conflito que exemplifica as relações de afrontamento, contradiçáo e antagonismo entre formaçōes ideológicas materializadas na inscrição dos sujeitos no simbólico.

\section{b) construção do simulacro na adjetivação do outro}

Conforme está em Indursky (1997), a designação e a adjetivação são processos de "determinação discursiva" que incidem sobre um nome (Encosto, Exu, etc.) com o objetivo de "saturar-lhe o significado para qualificálo a integrar seqüências discursivas afetadas por determinadas FDs" (Indursky, 1997, p. 177). A determinação busca um "fechamento do discurso" para que se produza um efeito de homogeneidade sempre ilusório. Desse modo, a construção da referência Encosto no discurso de FD1, para saturar os sentidos das diferentes designações de Encosto (Maria Bonita, Zé Pelintra, etc.), ou seja, para dotá-lo de "univocidade" (todos sabem o que é um encosto, o que faz um Exu), adjetiva tais designaçóes através de relativas que materializam a imagem do simulacro de FD2. Conforme a análise das seqüências discursivas de referência, a adjetivação do Encosto se apresenta nas duas formas de interpelação da interlocução Bispo $\rightarrow$ Encosto: Você que $X$ e $O / A Y$ que $X$, em que $Y$ é uma designação.

Na reflexão sobre o funcionamento das construções relativas como pontos privilegiados de articulação entre sentido, sintaxe e ideologia, remonto à análise das seqüências de nosso corpus aos textos de Pêcheux (1981) e Henry (1990).Segundo esses autores, as relativas são classificadasenquanto apositivas e determinativas pelas gramáticas levando-se em conta critérios puramente sintáticos. Enquanto as relativas apositivas seriam o lugar de um retorno do saber sobre o objeto, as relativas determinativas traçariam uma fronteira restritiva entre o objeto em questão e os outros de mesma classe. Entretanto, 
conforme apresenta Pêcheux (1981), há exemplos em que "a escolha entre as duas interpretaçôes não é evidentemente de natureza lingüistica", dependendo do posicionamento ideológico de quem as interpreta. Isso porque o funcionamento determinativo das relativas apresenta "uma relação inter-seqüência como se se tratassede uma relaçãointra-seqüiência” (Henry, 1990, p. 61), ou, em outras, palavras, a relativa determinativa implica um efeito subjetivo de anterioridade, de implicitamento admitido, um pré-construído que delimita, em última instância, fronteiras entre FDs.

Para dar conta da relação interdisaursiva entre FD1 e FD2 tal como essa se materializa na invocação do Encosto, observemos os seguintes quadros:

Interlocução Bispo $\rightarrow$ Encosto

\begin{tabular}{|c|c|}
\hline \multicolumn{2}{|c|}{ Forma de interpelação: $O / A Y$ que $X$} \\
\hline Nome (designaçáo):O/AY & Saturação (relativas): que $X$ \\
\hline Maria Molambo & (a) que ganhou champanhe \\
Maria Padilha & (b) que ganhou rosas \\
pomba-gira & (c) que ganhou cetim \\
pomba gira Rainha & (e) que ganhou um trabalho pago com cachaça, com uísque \\
espírito & (f) que vem atuando nesta pessoa há anos, há várias luas \\
Tranca-Rua & (g) que entrou ai e trancou a vida desse homem
\end{tabular}

Forma de interpelação: Você que $X$

(h) que ganhou trabalho pra destruir o casamento

(i) que recebeu um trabalho na Umbanda, na Quimbanda

Você

(j) que foi pago na cachoeira

(l) que recebeu quatro pés

(m) que recebeu uma oferenda na mata virgem

Debates do NER, Porto Alegre, ANo 6, N. 7, P. 11-78, JAN./Jun. 2005 
Tomando essa sistematização como uma família parafrástica da construção referencial das designações, determinada enquanto tal pela matriz de sentido de FD1, na observação das relativas das duas formas de interpelação, vê-se que alguns pré-construídos são partilhados, pressupostos pelas duas FD, como é o caso do conjunto de oferendas às entidades: relativas $a$, $b, c, e, j, l$, e $m$. Essa convergência, marcada lingüisticamente pela tendência para um funcionamento apositivo das relativas, aponta diretamente para a constituição heterogênea de FD1, pois se sabe, tal como escreve o Bispo Edir Macedo em seus livros doutrinários, que os bispos e pastores, assim como obreiros, devem dominar os saberes de FD2 a fim de que a invocação seja eficaz. Ao mesmo tempo, o enunciar esses saberes de FD2 é a prova da legitimação da eficácia simbólica das práticas de FD2, como bem lembra Oro, ao dizer que "a Universal não nega a existência das entidades afrobrasileiras, mas modifica o seu significado...” (Oro, 1997, p. 15).

Por outro lado, algumas relativas apontam justamente para a construção do simulacro de FD2 através da adjetivação das designaçôes das entidades afro, como pode-se perceber nas relativas $d, f$, $g$, e $h$, que não seriam aceitas por sujeitos de FD2 cuja inscrição na memória discursiva não é sustentada por pré-construídos tais como "a pomba-gira leva seus cavalos para a prostituição", "os exus atuam para destruir a vida de seus cavalos" e, no limite, "todas entidades afro são maléficas, portanto...". Observa-se assim que a forte indeterminação dos sentidosdessas designaçōes no interdiscurso tem como contrapartida uma forte tendência à determinação na língua, marcadamente no intradiscurso de FD1.

O processo de determinação discursiva das designaçōes das entidades em FD1 dá lugar a um equívoco que corresponde ao encontro, à indeterminação entre o funcionamento apositivo e o determinativo das relativas analisadas acima. Qualquer um desses funcionamentos, de fato, produz a construção discursiva do referente Encosto condizente com FD1, marcando na materialidade lingüística a luta ideológica pelos sentidos das palavras.

A partir disso, conclui-se, sob uma perspectiva discursiva, que, como disse o antropólogo Ronaldo de Almeida, "por umsincretismo às avessas, 
a IURD acabou produzindo sua Pombagira, seu Exu-Tranca Rua, sua Maria Padilha” (Almeida, 2003, p. 340). Para a análise de discurso, porém, é a saturação dos sentidos na inscrição do sujeito em FD1 que produz a tradução do Exu e da pomba-gira das religiōes afro para o Exu e a pomba-gira da IURD, como resultado de uma religiofagia ${ }^{18}$ que se alimenta/regurgita o simulacro da presa, determinando discursivamente tais designaçôes.

Tal saturação do sentido está presente no uso das palavras e é uma marca fundamental do dialogismo tal como o teorizou Mikhail Bakhtin. Para esse autor, os diferentes sentidos das palavras, aqui as designações Exu ou pomba-gira, entre outras, devem-se a acentos contraditórios que se cruzam no in terior de cada palavra - no e pelo en trecruzamen to dos discursos, tal como no processo de tradução que temos aqui por objeto. Como ótimo exemplo do dialogismo entre o discurso de FD1 e o de FD2, basta lembrar o nome de uma das reuniōes em que ocorre o ritual de libertação e cura: Sessão do Descarrego, em que a palavra sessão, que também designa os rituais determinados por FD2, apresenta o acento contraditório de pretenderse uma ação contra o efeito desses rituais, ainda que se utilizando dessa mesma palavra. Um dos imperativos dirigidos ao Espírito Santo marca bem o caráter dialógico do ritual de libertação e cura: os sujeitos-fiéis pedem que Deus desfaça os trabalhos feitos contra eles antes e alhures.

Contudo, a "demonização" das entidades das religiōes afro não se dá apenas designando o diabo com seus nomes. Lembro com Maingueneau (1984) que a tradução discursiva deve ser observada em diferentes planos discursivos, ou seja, não só no aspecto lingüístico, mas também como prática de uma comunidade discursiva. É preciso também tratar da invocação

${ }^{18}$ Tal expressão é corrente na literatura antropológica e sociológica sobre a IURD. Para Ari Oro, por exemplo, a IURD seria uma igreja religiofágica, literalmente, "comedora de religiāo". Essa "fagocitose religiosa”, como coloca Ronaldo de Almeida (2003, p. 341), caracteriza-se pela construção de um repertório simbólico, crenças e ritualística, incorporando e re-semantizando pedaços de crenças de outras religiōes, até mesmo de seus adversários. "A Igreja Universal, no seu processo de constituição, elaborou, pela guerra, uma an tropofagia da fé inimiga" (Almeida, 2003, p. 341). 
do lugar enunciativo do encosto dentro de determinações de ordem institucional, ou seja, da relação do estatu to dessa posição enquan to interlocutor com a cena discursiva em que se produz sua inscrição.

\section{A POSSESSÃO: QUANDO EU É UM OUTRO}

No discursoneopentecostal,a possessãodemoníaca é bastanteenfatizada sobretudo nas denominações de segunda e terceira ondas. Na IURD, a possessão apresenta traços singulares dado o dialogismo antagônico entre FD1 e FD2, conforme já se pode observar até aqui.

É preciso antes de tudo dizer que nesse item não se pretende tratar exaustivamente da possessão como fenômeno social, muito menos revisar uma numerosa bibliografia das áreas da etnologia e da antropologia sobre o assunto. A contribuição será o estudo discursivo da forma da ilusão da reversibilidade, mais especificamente, daquilo que Eni Orlandi, em seu estudo do discurso religioso, chama de transgressão. Segundo a autora, a transgressão é a forma ilegítima de (ilusão de) ultrapassagem do plano temporal para o plano divino, é uma forma de "tentar ocupar um lugar nunca ocupado, ou ocupável, pois ao se tomar o lugar, se se exclui" (Orlandi, 1987, p. 254).

No maniqueísmo instaurado pela religião, ao passo que a ultrapassagem legítima é aquela em que a ilusão de reversibilidade cria o sentimento de identidade com Deus, através de mecanismos próprios (fórmulas religiosas em seu caráter performativo), a transgressão está geralmente ligada à figura do Diabo. Como coloca a autora: "A transgressão pode ser ou uma quebra das regras do jogo - tal como a blasfêmia, a heresia, o pecado - ou a usurpação do lugar, tal como o pacto com o diabo" (Orlandi, 1987).

Porém não se deve ficar restrito a uma classificação que diga respeito somente ao discurso religioso cristão. No universo de FD2, por exemplo, a possessão aparece como uma forma de ultrapassagem legitima. É verdade que para um umbandista puro incorporar o Exu poderia ser ilegítimo, mas nem toda possessão é sinônimo de "pacto com o diabo". 
Antes proponho interpretar a possessão dos sujeitos-fiéis de FD1 como um efeito-sujeito ${ }^{19}$ produzido pela inscrição em uma rede de memória que materializa a contradição no seio de FD1. Enquanto incorporados pelos Encostos, ou seja, sendo um Encosto, os sujeitos só podem enunciar na filiação a uma ordem de saberes, que produz, no ritual de libertação e cura, o simulacro das possessões das práticas de FD2.

$\mathrm{Na}$ invocação do Encosto, a partir da interlocução Bispo $\rightarrow$ Encosto, novamente a alteridade negativa do sujeito-fiel aparece como tema do discurso:

Sdr8: Isso! Manifesta! Dá o teu grito! Dá o teu grito, DÁ O TEU GRITO! Porque essa pessoa veio aqui hoje para ser livre. E o seu trono vai ser quebrado agora. Vamos lá, Orixá! MANIFESTA AI!! O caboclo que ta aí, o Oxalá que ta aí, o Tupinambá, MANIFESTA, VAMOS! É UMA ORDEM!

Da perspectiva do lugar do sujeito-fiel, aqui no lugar de quem ouve falar de si, a possessão se produz como a identificação desse outro do fiel um outro que antes se inscrevia em FD2, essa pessoa cuja memória dessas práticas ainda ressoam na unidade que enuncia $e u$, com um ele com quem o Bispo (Deus) fala: o Encosto. Ou melhor, essa pessoa de que fala o sujeitobispo (eu do fiel) dá lugar ao ele que o sujeito-bispo invoca, como se conjurasse uma subjetividade do fundo de uma memória que se busca sempre recalcar, mas que se faz mister tornar presente.

$\mathrm{Na}$ possessão, o outro do fiel (que é ele mesmo (eu), heterogêneo, sua alteridade) ao ultrapassar o plano temporal em direção ao divino, de profano transformar-se em sagrado, "se se exclui", dá lugar ao ele (Encosto), que, por sua vez, enuncia dizendo $e u^{20}$.

\footnotetext{
${ }^{19}$ Por efeito-sujeito entendemos, com Pêcheux (1995), a evidência produzida pela inscrição de um sujeito na FD que o determina, fornecendo / impondo a realidade e seu sentido (eu sou exu) sob a forma da verdade.

${ }^{20}$ No próximo item trato do trabalho discursivo dessa voz outra que enuncia dizendo $e u$, na produção do simulacro da entidade afro-brasileira.
} 
Dessemodo, a possessãoaparece comoum efeito de sujeito produzido por uma filiação a uma rede de memória discursiva, nesse caso a relaçao de FD1 com FD2, que produz, no ritual de libertação e cura, uma tradução dos préconstruídos de FD2. A eficácia da invocação do Encosto está assim intrinsecamenterelacionada com a identificação dos sujeitos-fiéiscom os pré-construídos de FD2, ainda que traduzidos. Citando as palavras de Maingueneau,

"Em toda lógica o discurso convence porque se encontra nele o que já se sentia como presente em si, mais ou menos obscuramente. Reminiscência platônica que permite dizer "é isto mesmoh», o mesmo marcando a coincidência com uma verdade já lá da qual o texto seria somente a explicitação ou a repetição. A evidência que produz a adesão vem de fora e aí está a própria condição de possibilidade do conceito de discurso : que existam momentos e lugares para os quais uma configuração de sentido possa ser reconhecida por um conjunto de sujeitos como o Todo da verdade" (Maingueneau, 1984, p. 126) ${ }^{21}$.

Vê-se assim que a identificação da possessão enquanto transgressão implica uma auto-exclusão do sujeito-fiel para dar lugar ao sujeito-encosto, que se apresenta adverso ao lugar (templo) onde se manifesta e à verdade que ali se produz. Tal adversidade, compatível com os saberes de FD2 traduzidos, induz a dizer que os sujeitos levados para o altar, porque possuídos, são os não-sujeitos, os antípodas dos sujeitos de FD1, necessários, contudo, para o efeito de unidade desses mesmos sujeitos. Os sujeitos-encostos são importantes pela exemplaridade de seu desvio e de seu arrependimento, pois no final todos receberão a graça divina.

Quanto ao etos do sujeito-encosto, com relação à performatividade e ao estatuto do sujeito-bispo na invocação do Encosto, recortou-se a forma "Dá teu grito" como uma marca da ordem que o Espirito Santo dá ao Encosto. Justamente, uma das primeiras materialidades que confirmam a transgressão e, portanto, a legitimidade do poder do sujeito-bispo na sua relação privilegiada com o Espirito Santo, é um grito que os sujeitos-encos-

\footnotetext{
${ }^{21}$ Tradução minha.
} 
tos emitem, além de se debaterem para se livrar do sujeito-obreiro ou se jogarem no chão. Os gritos - que podem ser vistos como transformaçáo do símbolo em referente (Reboul, 1980) - , à medida que vão aumentando em quantidade, confirmam a presença do Mal no interior do templo: tudo o que foi dito e feito antes disso se confirma ao mesmo tempo.

Uma vez presente o outro enquanto entidade afro, desde já se tem um simulacro da entidade, um "Exu da Universal", lembrando as palavras do antropólogo Ronaldo de Almeida, pois as entidades estão aí são todas Encostos = equivalentes ao Mal cristão. Na seqüência do ritual, os representantes de Deus e do Diabo dialogam na frente dos homens ansiosos por uma vitória. É chegado o momento do diálogo fundamental.

\section{A INTERLOCUÇÃO DISCURSIVA NO ATO DE EXORCISMO}

Recortou-se esse terceiro momento da prática discursiva de libertação com base na análise do corpus, que apresenta uma ruptura entre a expulsão do Encosto dos corpos dos sujeitos-fiéis em frente ao altar, o que se dá muitas vezes sem a manifestação dos encostos, e o ato de exorcismo, que dá prosseguimento ao ritual.

Antes do diálogo com o encosto em cima do altar, há a expulsão dos encostos que não manifestaram mas que estão no corpo dos sujeitos-fiéis. O enunciar SAI!, ato de expulsão dos encostos, se refere principalmente aos efeitos dos encostos que não manifestaram, que estão no corpo do sujeitofiel. Além desses, há, portanto, sujeitos-encostos que resistem à expulsão coletiva em diferentes pontos do Templo, se não já reunidos em cima do altar. A seguinte seqüência exemplifica o ato de expulsão:

Sdr9: "Todo mal! Toda dor!" Em nome de Jesus, em nome do Senhor Jesus, diga: "SAI?" $\left\{\right.$ SAI! ${ }^{22}$, de novo! $\{$ SAI! $\}$, outra vez $\{$ SAI!\}, mais forte $\{$ SAI! $\}$, todo

\footnotetext{
${ }^{22}$ Representamos entre chaves a repetição que os sujeitos-fiéis fazem do dizer do sujeito-bispo.
} 
encosto \{SAI!\}, toda praga \{SAI!\}, todo mal! SAI! SAI! SAI! SAI! \{ SAI! SAI! SAI! SAI!\} e não volte nunca mais!

Repetindo SAI!, tantas vezes quantas o sujeito-bispo determinar, os sujeitos-fiéis que até então estavam com as mãos nas cabeças tiram-nas, todos ao mesmo tempo, com violência e energia. Crê-se que ao fazer tal movimento em direção à porta da Igreja se expulsa os Encostos para fora do espaço físico do templo, mais precisamente para o inferno. Para ter eficácia, o ato de expulsar os Encostos (que se marca com o imperativo SAI!) é repetido pelos sujeitos-fiéis enquanto o sujeito-bispo regra a repetição com expressôes do tipo "de novo", "mais forte", "outra vez", etc. Cada vez que enunciam SAI!, os sujeitos-fiéis repetem também o gesto de retirada das mãos de suas cabeças, marcando assim sua participação ativa como condição de eficácia da performatividade da expulsão.

Depois dessa expulsão, no altar estão de cinco a dez sujeito-fiéis possuídos, resistindo. Desses, o sujeito-bispo traz algum para o centro do altar e regula seu posicionamento segundo as regras próprias da forma de exorcismo de FD1:

Sdr10: Levanta a cabeça. Levanta a cabeça. Levanta a cabeça. LEVANTA A $C A B E C ̧ A ! ! !$ Que não pode o que!, aqui cê não faz o que cê pode, cê faz o que te mandam fazer. Aqui quem te manda somos nós. Levanta a cabeça! Seu derrotado!

Como o sujeito possuído se mantenha relutante a tal posicionamento, de cabeça baixa, recusando ir para onde o sujeito-bispo o carrega, na interlocução Bispo $\rightarrow$ Encosto a autoridade do sujeito-bispo sobre o possuído se marca formalmente através de imperativos como levanta a cabeça, expressões do tipo Isso! e também na variação da ênfase da voz do sujeitobispo, que assume um tom de ameaça, chegando mesmo a gritar sem o microfone, diretamente ao ouvido do possuído.

Sdr11: Levanta mais! Presta atenção, encosto, cê não tá na tua casa não! Aqui você deve respeito. Então manifesta ai o mais forte. Eu quero o chefe, 
manifesta ai o da morte. Segura o corpo dela ai, manifesta amarrado, o chefe, com a mão pra trás, amarrado. De joelhos. Levanta a cabeça dela. Fica em pé. EM PÉ! Isso!

Percebe-se assim que a "guerra no campo espiritual", segundo FD1, consiste em desmascarar a verdade sobre a natureza das entidades afro, agora fora de sua "casa" e portanto submetidas a u ma lei que, em certa medida, lhes é estranha.

Conforme se pode observar através do estudo de Bastide (1973), o transe das religiões afro se dá em condições sociológicas bem determinadas, assim como o despacho das entidades ao final do ritual. Se é assim para o transe mediúnico das religiões afro, também o é para a possessão no ritual de libertação e cura da IURD: existem etapas socialmente decodificadas, incluindo a enunciação de certas palavras em momentos determinados. Etapas que procuro analisar discursivamente ao longo desse trabalho.

Como já observou o sociólogo Ronaldo de Almeida (2003), no ritual de possessão da IURD, qualquer pessoa (não somente pais e filhos-de-santo) pode ser possuída, sem ser necessário, portanto, um ritual de iniciação cuja duração pode variar de algumas semanas a alguns meses. De fato, como explica Almeida, são duas as maneiras em que o fiel da IURD pode entrar em contato com os encostos e estar à mercê da possessão. Ou a pessoa foi vítima de algum feitiço, ou teve algum contato com a casa de religião (incluindo ingestão de alimentos sagrados e qualquer participação no ritual). Sendo apenas essas as condições estatutárias do locutor que pode enunciar sua possessão, esse é mais um traço do simulacro do discurso de FD2: na incorporação de seu outro, os sujeitos de FD1 enunciam dentro de um espaço que lhes permite prescindir dos rituais de invocação próprios de FD2 para suas entidades, apresentando sua presençanão mais como o "ponto culminante, de extrema sacralização do ritual, mas em posição de pólo negativo extremo da manifestação do mal" (Almeida, 2003). Há assim um alargamento do campo de ação do mal enquanto entidade afro, pois essas entram em contato não só com quem as cultua, mas com qualquer um que esteja fora da proteção do Espírito Santo. 
Além disso, as entidades afro, que segundo as coerções de FD2 são invocadas para dar consultas aos fiéis, demonstrando nesse momento graus variáveis de intimidade com os circundantes, na prática regulada por FD1 essas entidades são invocadas para serem expulsas depois de forte deboche e escárnio, segundo os mecanismos discursivos descritos na análise.

Nesse momento costuma-se enfatizar que não é o sujeito-fiel que sofre humilhações no centro do altar. Seu lugar de enunciação é o lugar de uma diferença, de uma ruptura que se instaura entre o dizer do sujeito-fiel incorporado, que se exclui em seu silêncio, e o dizer do sujeito-encosto, que enuncia enquanto entidade afro. É bastante comum o sujeito-bispoenfatizar que não se dirige à pessoa, ao fiel incorporado, mas sim ao encosto, à alteridade do próprio discurso de FD1.

Voltando à análise, em primeiro lugar, característica do toda representação de exorcismo é a forma em que se dá a enunciação: trata-se sempre de um jogo de pergunta-resposta-pergunta-resposta, o "gênero literário que representa o documento mais próximo do interrogatório" (De Certeau, 1982). Ao invés de responderem aos fiéis aconselhando-os ou repreendendo-os, as entidades afro devem responder à Lei do Espírito Santo, que lhe condena e ameaça a existência por lhe tomar em falta. As regras discursivas de FD1 produzem a colocação do locutor e do interlocutor em lugares bem determinados, cada um com seus direitos e deveres, sobremodo ao dizer e ao modo de dizer.

Um outro aspecto importante é que, dado seu caráter fundamentalmente dialógico, essa ameaça se dirige para fora dos limites espaciais do Templo da Fé, tendo destinatários que não necessariamente estão presentes no ritual de libertação e cura. Ao admoestar e exorcizar os encostos, os sujeitos de FD1 mantém um diálogo conflituoso, fruto de embates ideológicos que se materializam contraditoriamente em FD1 e FD2, atravessando suas materialidades lingüísticas.

Para dar conta da interlocução do ato de exorcis mo enquan to jogo de perguntas e respostas de um lado e enquan to embate entre formaçôes ideoló gicas materializadas em FDs de outro, trago para a análise as reflexôes de Freda Indursky, que no excelen te trabal ho $A$ Fala dos Quar- 
téis e as Outras Vozes (1997) teoriza sobre o processo de interlocução discursiva.

O processo de interlo cução discursiva é constit uído de uma dupla articulação interdependente de uma interlocução enunciativa e uma interlo cução discursiva. Ao passo que a interlocução enunciativa se dá em uma cena enunciativa materialmente completa - locutor, interlocutor, situação, espaço, tempo -, a interlocução discursiva consiste na "inter locução entre sujeitos de discursos dispersos em espaços discursivos diferentes, afetados possivelmente por FD igualmente diversas" (Indursky, 1997, p. 139).

Como aponta em seu trabalho, o nível de interlocução enunciativa do discurso militar apresenta em eu (qualquer um dos presidentes da terceira república) e $t u$ (parlamentares da Arena, estudantes universitários, militares, etc.) pólos bem definidos e de bastante visibilidade, sendo que não há intersubjetividade entre esses dois pólos dada a natureza da alocução presidencial - só o presidente fala. Já ao nível de interlocução discursiva, a tomada de palavra de um locutor mobiliza a figura do sujeito do discurso da FD em questão, que pode se mostrar indefinido ou indeterminado, assim como o outro que é por ele interpelado, não estando a cena discursiva, portanto, limitada espacialmente pelo espaço físico em que a alocução ocorre, na presença do interlocutor. Desse modo, tomando o interlocutor como mediador na cena enunciativa, o sujeito do discurso, que fala pela voz do locutor, interpela o outro que se institui como seu destinatário na cena discursiva.

Com base na noção de processo de interlocução discursiva, são examinadas agora as seqüências recortadas do corpus. São seqüências de perguntaresposta recortadas do ato de exorcismo, referentes ao momento em que o sujeito-bispo "dialoga" com o sujeito-encosto.

A partir do posicionamento descrito no início dessa interlocução, o sujeito-bispo mantém com o sujeito-encosto um diálogo onde geralmente se repetem as seguintes perguntas e respostas:

Sdr12 Bispo: Qual o teu nome? (sobre a origem e identificação do mal) Encosto: EXU-DA-MORTE!

Debates do NER, Porto Alegre, ano 6, N. 7, P. 11-78, JAN./Jun. 2005 
Sdr 13: B: Que que tá fazendo aí? (sobre os males e as suas causas) E: Tô botando um derrame nessa desgraçada.

Sdr14: B: Você recebeu feitiço do quê? Que que cê recebeu? (sobre como os encostos entraram na vida do sujeito) E: Charuto! Cachaça! Sete galinha! A meia noite.. rrrr.

Conforme argumenta Almeida (2003, p. 323), "a entrevista visa descobrir a origem dos demônios, os males causados e a maneira pela qual eles entraram nos corpos das pessoas". Sendo assim, para a perspectiva discu rsiva, as respostas no dizer do sujeito-encosto estão em relação parafrástica com os enunciados da invocação do Encosto, principalmente na interlocução Bispo $\rightarrow$ Encosto, ou seja, obedecem a uma ritualização própria à eficácia do ritual de libertação e cura (ver 5.2). Retomando esses enunciados, vemos que as respostas do sujeito-encosto vêm ao encontro da representação que se constrói do Encosto no momento da interpelação Bispo $\rightarrow$ Encosto durante a invocação do Encosto - responder desse modo às perguntas do sujeito-bispo é responder à interpelação da invocação do encosto.

Um primeiro traço da enunciação do sujeito-encosto é, portanto, seu lugar de complementaridade que, ao responder às questões do sujeito-bispo, legitima todo o discurso de FD1 a partir da invocação do Espírito Santo, re-atualizando assim uma memória da sintaxe própria ao discurso de FD1 no ritual de libertação e cura. Ao dizer quem é, o que está fazendo, em troca de quê e desde quando, o sujeito-encosto, identificado em certa medida com FD1, enuncia o simulacro do lugar de dizer da entidade afro de FD2, legitimando assim a imagem de entidade afro dita pelo sujeito-bispo durante a invocação do Encosto.

Segundo o que tenho apresen tado do simulacro de FD2, a identificação que se pode observar na enunciação das respostas se produz no seio de uma relação de força entre discursos em confli to. A autorid ade do dizer do sujeito-bispo de exigir a ação do interlocutor, nesse momento crucial do ritual de libertação e cura, parece se dirigir para uma estranheza que não faz parte da unidade de seu discurso, algo que é 
preciso elimin ar porque outro, estran ho, conden ado. O dizer do sujeito-encosto, inserido em uma intrad iscursividade ditada pelas regras de FD1, vem marcar assim uma ruptura "suturada" em que um alhures do discurso se atualiza no discurso.

A partir da leitura do texto $A$ linguagem alterada, de Michel de Certeau (1982), poderia se colocar a questão de saber se no dizer do possuído, sob essa rup tura "suturada", se en contra um outro discurso. De fato, ao analisar o discurso das possuídas de Loudun, grupo de cerca de vinte religiosas ursulinas no século XVI, que eram interrogadas tanto por médicos quanto por exorcistas, De Certeau chega à conclusão de que não se trata de um discurso outro, mas de uma alteração da/na linguagem, pois apesar da ruptura que separa um saber classificador de um saber classificado, o dizer das possuídas enquanto limite não tem a mesma estrutura discursiva que o saber demonológico ou médico ( De Certeau, 1982, p. 247), não havendo, nesse caso, um sentido oculto que o exorcismo trataria de desvelar. Antes, trata-se mais do "retorno do outro no discurso que o proíbe", uma oscilação do texto na direção do fora-do-texto, de maneira que esse permanece interior ao texto do saber (De Certeau, 1982, p. 250). A relação do discurso com essa transgressão, que não é discurso, mas alteração da/na linguagem, é fundamentalmenteassimétrica, pois no jogo de perguntas e respostas, o dizer da possuída está submetido a uma posição que diz "Eu sei melhor do que tu aquilo que me dizes", ou então, "Meu saber pode se colocar no lugar de onde falas".

Trazendo essas reflexões para a análise do processo de interlocução discursiva do ato de exorcismo, procuro demonstrar que 1) a alteração de que fala De Certeau é da mesma ordem da que ocorre no discurso neopentecostal da IURD e 2) apesar disso, diremos que o dizer do sujeitoencosto $e ́$ o indício da existência de um discurso, que se apresenta como simulacro de discurso, traduzido. Nas condições sócio-históricas de produção do discurso neopentecostal, determinado por seu exterior específico, o interdiscurso que lhe é constitutivo enquanto outro pode ser definido como necessariamente contendo, entre outros, os saberes do discurso de FD2, aind a que esse discurso-outro não possua limites lingüisticamente 
identificáveis, uma vez que FD1 e FD2 se constituem reciprocamente num mesmo espaço discursivo.

Quanto à primeira questão, De Certeau escreve que a alteração produzida na linguagem do discurso, que não chega a configurar um outro discurso, se dá na tarefa sempre repetida de denominação do que é esse dizer estranho e de que ele fala. Trata-se do jogo entre o lugar estável que espera o dizer do possuído quando lhe perguntam quem és? e a evanescente pluralidade de lugares por que derivam as possuídas.

"O teatro diabólico é caracterizado pela relação, sempre incerta, entre os lugares fixados para todos os atores por alguns dentre eles (o exorcista ou o médico compõem a cena, designando a cada um seu papel, da mesma forma que o psiquiatra fixa ou tende a fixar o papel para o doente), e a mobilidade de certos atores (as possuídas) deslizando de lugar em lugar". (De Certeau, 1982, p. 252)

Muitos desses traços estão presentes na análise do ritual de libertação e cura. Do mesmo modo que o médico ou o exorcista do século XVI, o sujeito-bispo exige do sujeito-encosto a assunção de uma identidade que, até esse momento do ritual, é apenas imaginada, esperada, mas nunca totalmente certa e definida, fazendo assim com que os nomes próprios das entidades das religiões afro venham aparecer no lugar do nome próprio de diabo. É importante dizer que tal identificação só se dá a partir de uma exclusão radical, a do sujeito-fiel que, quando possuído, acaba por enunciar "Eu é o outro". A alteração de que fala De Certeau consiste então nessa "perturbação que conota a desarticulação do sujeito locutor ("eu") e de um nome p róprio definido". Assim, o dizer do possuído cria sempre um desvio com relaçáo ao postulado: eu = nome próprio, "Eu sou João" $\rightarrow$ "Eu sou Exu”.

Tal deriva lingüístico-discursiva é bastante visível quando o sujeitobispo ordena que se manifeste o encosto mais forte, o mais poderoso. A possibilidade de o sujeito ser possuído por vários encostos pode ser vista tanto como uma atualização do saber bíblico "Legião, pois somos muitos", 
como mais uma tradução da possibilidade em FD2 de receber várias entidades, sendo impossível afirmar qualquer origem exata de tal saber ${ }^{23}$.

Uma vez examinadas as semelhanças entre a alteração da linguagem identificada por De Certeau e a de que me ocupo nesse trabalho, se pode dizer que na interlocução Bispo $\longleftrightarrow$ Encosto, ao nível enunciativo - diferentemente da interlocução estudada por Indursky, em que os lugares do locutor e interlocutor se apresentam bem definidos -, é a indefinição (relativa, pois se sabe que será uma entidade afro, mas não se sabe qual exatamente) que possibilita a denominação e, por via desse processo discursivo, a tradução em simulacro do discurso. Vejamos o esquema no quadro seguinte que representa a cena enunciativa da interlocução Bispo $\leftarrow \rightarrow$ Encosto:

Cena enunciativa do ato de exorcismo

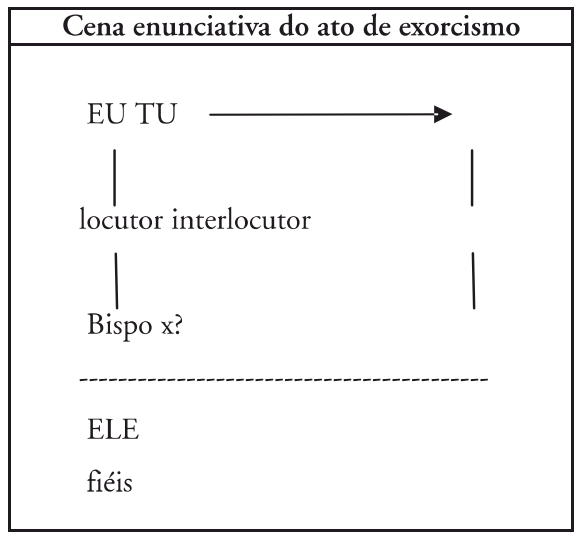

\footnotetext{
${ }^{23}$ Transcrevemos o seguinte exemplo que atesta uma hierarquia que subverte o saber de FD2 em dois sentidos:

P. Cê é o chefe aí? Tem mais forte que você aí?

R. Nãaaao, é o exu-da-morte que vai mata ela, seu desgraçado!

Em primeiro lugar, um das condiçóes rituais para poder receber uma entidade da linha cruzada é já ser cavalo de um orixá ou caboclo, o que não se observa na ritual de libertação e cura, conforme dissemos ao comentarmos o trabalho de Bastide. Em segundo lugar, de acordo com as regras de FD2, são os orixás as entidades mais poderosas (algumas até associadas aos santos católicos no sincretismo), sendo os exus entidades muito fortes e perigosas mas submissos ao poder dos orixás.
}

Debates do NER, Porto Alegre, ano 6, N. 7, p. 11-78, JAn./Jun. 2005 
Observa-se assim que a tarefa do sujeito-bispo, assim como a dos exorcistas e médicos no caso de Loudun, é sempre a de identificar a incógnita $x$ e, identificando-a, fazer com que essa associação (alteração) se desfaça, para a maior glória de Deus.

Novamente dialogando com o trabalho de Indursky (1997), um outro aspecto que difere a interlocução enunciativa do discurso dos militares do discurso do ritual de libertação e cura, ambos discursos autoritários, é a rep resentatividade do pronome eu no dizer do locutor e do interlocutor ${ }^{24}$, o que caracteriza uma reversibilidad e fortemente condicionada às regras de FD1, a ritualização própria do ritual de libertação e cura. Também aqui, assim como no caso dos militares, porém menos acentuadamente, a representação do sujeito do discurso se marca fortemente pelo nós. Entretanto, se no discurso da terceira república não havia reversibilida de na alocução presidencial, aqui é justamente na resposta do interlocutor, no lugar lingüístico $e u$, como diz De Certeau, que ocorre uma desaprop riação, se é verdade que "eu" é, na linguagem "signo único, porém móvel que está ligado ao exercício da linguagem e declara o locutor como tal" quando esse "se apropria da língua inteira designando-se como eu" (Benveniste, 1991, pp. 258-262). Tal desapropriação, marca da alteração da linguagem dos possuídos, vem dar lugar a um outro que enuncia dizendo eu e portanto articulando um enunciado produzido alhures (existem Exus => FD2) com uma enunciação do discurso: $\mathrm{Eu}=\mathrm{Exu}$ (do mal, da pobreza, da doença => FD1).

Já se observou anteriormente o mecanismo de determinação do outro na interpelação do Encosto. Conclui-se que as designações Exu, Pombagira, Orixá, ao serem enunciadas a partir de uma inscrição em FD1, produzem efeitos de sentido diferentes daqueles produzidos em FD2 através de determinações relativas que ora sustentavam certos saberes de FD2, isto é, legitimavam alguns de seus pré-construídos, ora traduziam outros pré-

${ }^{24}$ Está aí incluída toda a série pronominal (meu, minha, meus) como também a declinação verbal.

Debates do NER, Porto Alegre, ano 6, N. 7, P. 11-78, Jan./Jun. 2005 
construídos que se transformaram então em saberes da ordem do proibido de dizer de FD2. A relação dialógica que constitui FD1 e FD2 em um mesmo espaço discursivo, entretanto, torna difícil delimitar a "propriedade" de certos pré-construíd os, uma vez que é impossível pensar em termos de FD homogênea, mas sim em unidade dividida, em compartilhamento das palavras e desacordo dos sentidos.

Pois bem, retomando o processo enunciativo da designação, tínhamos visto que as designações (aqui nome próprio) se produziam a partir de um confronto de lugares enunciativos que recorta e constitui um campo de "objetos" pela própria temporalidade do acontecimento, ou seja, pelas condiçõos sócio-histó ricas de produção do sentido e do sujeito. Entendemos assim que, quando um sujeito de FD2 enuncia eu = Exu e um outro de FD1 enuncia eu = Exu (nas condiçõos discursivas do ato de exorcismo), os lugares enunciativos em confronto se transformam produzindo "o recorte de um outro memorável, de um outro campo de "objetos" relativos a um dizer" (Benveniste, 1991, p. 40). Nesse sentido se pode dizer que a transgressão no discurso enquanto possessão, objeto da análise, se dá a partir de um recorte de um memorável constituído na relação conflituosa entre FD1 e FD2, sendo esse efeito-sujei to uma inscrição do sujeito na memória discursiva de um espaço discursivo determinado sócio-histór icamente.

Para concluir a respeito da questão crucial do momento de nomeação/ classificação e retomar o segundo ponto do diálogo que faço com o trabalho de Michel De Certeau, se pode dizer que, se na análise que De Certeau fez do discurso das possuídas de Loudun, a deriva lingüística (eu = nome próprio - outro) era a marca de uma alteridade que não era discurso, na análise que fazemos do processo de interlocução discursiva do ato de exorcismo, a deriva lingüística que observamos no nível da interlocução enunciativa é uma marca do simulacro que FD1 faz do discurso de FD2 no nível da interlocução discursiva - sendo essa tradução uma propriedade da relação FD1/FD2. Assim, o dizer do outro que parece enunciar "eu sou o outro" é na verdade uma cópia desigual da ord em do mesmo, a tradução do 
discurso-outro no mesmo ${ }^{25}$. O dialogismo aqui assume sua forma mais aberta, ainda que, como o discurso de FD1 é um discurso autoritário, tenda fortemente para o monologismo, na surdez que se produz para o discurso outro, negando-lhe qualquer pretensão à verdade.

Desse modo, se na análise que De Certeau faz do que ocorreu em Loudun, o teatro barroco da possessão é a "vitória de uma ordem", o ato de exorcismo do ritual de libertação e cura é a vitória de uma disputa, de uma polêmica entre iguais em posição assimétrica, onde as condições de possibilidade da subjetividade religiosa afro são determinadas pela hegemonia dos saberes cristãos na formação social brasileira.

\section{RESISTÊNCIA AO SIMULACRO OUSIMULACRO DA RESISTENNCIA?}

Para concluir o exame da interlocução Bispo $\leftarrow \rightarrow$ Encosto, volto para análise das perguntas e respostas do ato de exorcismo. Disse anteriormente que estas estão submetidas a uma ritualização própria para o ritual de libertação e cura, constituindo assim uma sintaxe discursiva do ritual. Acredito que esse é um argumento forte para a existência de um discurso-outro traduzido, não se tratando apenas de uma alteração que não é discurso, como no caso estudado por De Certeau. Quando responde às perguntas do bispoexorcista, o dizer do sujeito-encosto constrói a representação diferenciada de um mito afro, enunciando um nome, objetivos e oferendas requeridas que se assemelham muito àqueles ditos em FD2, mas que são, porém, tra-

${ }^{25}$ É também uma materialidade desse simulacro o que podemos chamar de simulacro material da língua. Com isso entendo a tradução das variaçōes fonológicas da fala das entidades em FD2, notadamente, como pude observar, as variaçōes $[\mathrm{r}] \rightarrow[\mathrm{l}] \mathrm{e}[\mathrm{s}] \rightarrow[\mathrm{x}]$. No dizer dos antropólogos (por exemplo, Correa , 1994), as entidades no terreiro se expressam em "português ruim", ao trocar os sons $[\mathrm{r}]$ por [l] e [s] por [x], como, por exemplo, nas palavras guriazinha $=$ [guliaziña $]$ e assim $=[$ axim $]$. Sob a perspectiva discursiva, o fato de que tais variações não sejam encontradas na enunciação de FD1 indica um simulacro material da língua resultante do processo discursivo próprio da relação interdiscursiva FD1/FD2.

Debates do NER, Porto Alegre, ano 6, N. 7, P. 11-78, jan./Jun. 2005 
duzidos em outros próprios ao ritual de libertação e cura. Além de representar o mito de forma diferenciada ao repetir um dizer próprio às determinações de FD1, também o etos discursivo do sujeito-encosto confirma essa tradução de que falamos, corroborando a argumentaçáo de Ronaldo de Almeida sobre a singularidade do transe da IURD. Nos termos do sociólogo,

"se o transe narrado já pertence à Igreja Universal, as entidades, conseqüentemente, já fazem parte do seu universo. Ao adquirirem autonomia ness e espaço, as entidades receberam atribuições específicas, e todas relacionadas a males concretos da vida. Segundo os pregadores, a Pombagira, por representar uma prostituta e por levar as pessoas ao homossexualismo, é a causadora da Aids; o Preto-Velho, por andar curvado, causa as dores na coluna; o Exu Tranca-Rua gera a miséria; os êres atingem fisicamente as crianças;o Exu da Morte, por sua vez, motiva o suicídio.Em vez do diagnóstico de uma doença ou de qualquer desgraça, a Igreja vem formulando paulatinamen te uma anatomia da poss essão, conferin do às entidades atribuiçōes e performances por vezes diferentes das registradas no espaço de um terreiro" (Almeida, 2003, p. 340).

Seguindo esse raciocínio, a tradução que FD1 faz de FD2 tem, no simulacro material da língua, assim como na necessidade de responder a verdade (quando Exus e Pombagiras não necessariamente seguem tal preceito nos terreiros), traços do simulacro da possessão incorporada. Por outro lado, como já foi dito, há um certo nível de resistência que é necessário para configurar a negatividade e antagonismo das entidades no ato de exorcismo, como nos seguintes exemplos recortados do corpus:

Sdr15: P. Pomba-gira o que?

R. Ha, ha, ha, ha!!! é o meu nome, seu IDIOTA!

Sdr16: P. Ce é o chefe aí, tem mais forte que você aí? R. Nãaaao, o exu da morte que vai mata ela, seu DESGRAÇADO!

P. Quem é o chefe, é ele?

R PÁRA DE ME FAZE PERGUNTA, SEU BOCABERTA!!! 
Tais podem ser indícios de uma resistência do sujeito-encosto que antes de ser negada ou repelida, serve de pólo negativo para confirmação da eficácia do ato de exorcismo. A adversidade do sujeito-encosto se sustenta assim em seu caráter essencial de mau-sujeito, de outro estrangeiro.

Além da resistência ao controle corporal, apresento um exemplo de mal-entendido no jogo pergunta-resposta como outra manifestação da materialidade da resistência no/ao discurso:

Sdr17: Bispo. Há quanto tempo cê tá ai?

Encosto. Sss sss sss muito pago, muito dinheiro!

A resistência ao discurso no discurso se apresentaria assim como não cooperação ou como equívoco, entendido como o que é próprio da língua (e seu impossível) em seu encontro com a história (contradição) sob a forma da "falta, do excesso, do repetido, do parecido, do absurdo, do nonsense", etc. (Leandro Ferreira, 2000, p. 108).

Mais um exemplo de um ponto de resistência ao dogmatismo do discurso, agora relativo ao riso:

Sdr18: Bispo: De joelhos, demônio, rápido! Você sabe que é obrigado a obedecer. Rápido, demônio! Não tenho tempo a perder com você, não. RÁPIDO! Pára de palhaçada, cê sabe que você é obrigado. Encosto: EU VO APANHÁ!!!

Bispo: Apanhá lá embaixo? Ce vai apanhar aqui em cima primeiro! (risos dos sujeitos-fiéis)

Tal é um exemplo de como o riso pode ser um "sintoma da dimensão que nos aproxima do equívoco da língua, lugar de encontro privilegiado entre o sentido, a sintaxe e o discurso" (Leandro Ferreira, 2000, p. 111), surgindo dentro do Templo da Fé não rechaçando a seriedade, mas purificando-a de sua unilateralidade e didatismo - identificado pelo humor.

Penso assim que, mesmo sendo possível interpretar a resistência ao discurso no discurso como uma estratégia que, na verdade, estaria a favor do discurso, ou seja, estaria funcionando como simulacro da resistência, an- 
tes interpreto a resistência dos sujeitos-encostos como resistência ao simulacro, como lugar on de o discurso "brinca com fogo", jogando com seus limites sem delimitar à distância suas fronteiras. O lugar do sujeito-encosto seria o lugar da emergência da contradição interna de FD1 na abertura ao seu interdiscurso, na medida em que a possessão se atualizaria como um efeito de memória que instaura uma modalidade de contra-identificação no ritual de libertação e cura de FD1.

\section{O SILENCIAMENTO DA ALTERIDADE NA CONFIRMAÇÃO DA LIBERTAÇÃO}

Chamo de confirmação da libertação o quarto e último momento do ritual de libertação e cura. Desmascarado, humilhado, culpado, o encosto foi finalmente exorcizado do corpo do sujeito-fiel. Depois da enunciação coletiva repetida da fórmula religiosa Queima!, que os sujeitos de FD1 enunciam com um tom agressivo e antagônico, por vezes chegando a bater com os pés no chão demonstrando muita raiva, instaura-se um silêncio momentâneo dentro do Templo da Fé. Todos os olhares se voltam então para o centro do altar, onde algo de milagroso acabou de acontecer: um sujeitofiel foi libertado do jugo que o diabo lhe impunha. Toda a atmosfera de batalha e de guerra que tinha seu início no começo da invocação do Encosto e seu clímax no ato de exorcismo agora desaparece dando lugar a uma atmosfera de calma, tranqüilidade, própria à visita do Espírito Santo. Automaticamente depois que o sujeito-bispo pára de repetir as fórmulas religiosas Queima! ou Sai!, uma melodia harmoniosa, produzida por um órgão eletrônico preenche o silêncio assim que o sujeito-libertado toma a palavra.

A tomada de palavra da posição enunciativa do sujeito-liberto, que se atualiza após o ato de exorcismo, se dá em condições determinadas pelo dizer do sujeito-bispo e, em última instância, pelas coerçôes semânticas de FD1 em sua relação interdiscu rsiva com FD2. Também aqui, como na interlocução do exorcismo (Bispo $\longleftrightarrow$ Encosto), a potencialidade subjetiva do interlocutor obedece ao jogo de perguntas e respostas determinado pelo dizer do sujeito-bispo. 
Uma vez eliminada a possessão, a subjetividade do sujeito-liberto implica a exclusão, a interdição do dizer do sujeito-encosto, do dizer desse outro que, a partir desse momento do ritual de libertação e cura, é da ordem do não possível de dizer, do interdito. Nunca foi observado que, depois do ato de exorcismo, algum sujeito-fiel viesse a incorporar um encosto, o que significa que tanto em FD2 quanto em FD1 há regras discursivas próprias para a possibilidade e legitimação da possessão.

Essa exclusão do dizer do sujeito-encosto e a emergência da subjetividade do sujeito-liberto são marcadas pelo retorno à articulação do contrato social da linguagem de que falávamos ao comentar o trabalho de Michel De Certeau sobre a possessão em Loudun. Vimos que na possessão havia uma desarticulação no postulado eu = nome próprio, decorrente do que De Certeau caracterizou como uma "perturbação que conota a desarticulação do sujeito locutor ("eu") e de um nome próprio definido", quando o sujeito en unciava dizendo "eu sou o outro" (De Certeau, 1982, p. 253). A tarefa do exorcista é então identificar esse outro classificando-o dentro de uma ordem de saber que se apresenta como dominante com relação ao dizer do possuído:

"O essencial da terapêutica, na possessão, quer seja na África, quer na América do Sul, consiste em nomear, em dar um nome àquele que se manifesta como falante, mas incerto e portanto indissociável de perturbações, de gestos e de gritos. Uma alteração se produz e a terapêutica, ou o tratamento social consiste em dar um nome, já previsto nos catálogos da sociedade, a esta palavra incerta. A tarefa dos médicos e dos exorcistas é a nominação, que visa a classificar as falantes num lugar circunscritopelo saber que estes médicos ou estes exorcistas detêm". (De Certeau, 1982, p. 245).

Assim, depois de identificar isso que fala como entidade afro, ou seja, classificar o dizer da possessão enquanto simulacro do discurso de FD2, a eficácia do ritual de libertação e cura está na construção e demolição desse lugar do possuído, numa lógica que vai da não-identificação à identificação e, finalmente, termina com a expulsão. Lembramos que a identificação desse lugar em FD1 está intrinsecamente ligada ao discurso de FD2, e esse é o 
indício de que, diferentemente do que ocorre em Loudun, essa alteração da linguagem pressupóe um outro discurso, do qual pretende-se afastar através da acusação e da condenação.

Desse modo, o lugar que antes enunciava Eu = Exu, confirma a eficácia do ritual de libertação e cura respondendo à mesma pergunta do sujeito-bispo com uma resposta diferente:

Sdr19: Bispo: Respira fundo. Como é seu nome?

Fiel: Clarissa.

O modo de enunciação se transforma com a transformação da subjetividade que emerge no ritual de libertação e cura, pois a formação discursiva prescreve diferentes modos de enunciação para as diferentes posições enunciativas que nela se inscrevem. Assim, enunciar $e u=$ Clarissa, implica estar livre de todos os "adjetivos" corporais com que a subjetividade do sujeito-e ncosto se caracterizava: posição curvada do corpo, voz rouca, agressividade - e assim também estar livre da alteridade negativa, causa do infortúnio e da desgraça. Em outras palavras, representa o silenciamento que busca definir as fronteiras de FD1, ainda que essa identificação possa ser efêmera como condição de existência do discurso de FD2. Observa-se que esse "voltar a si" (eu sou eu) do sujei to-fiel libertado é acompanhado de um ligeiro mal estar e, como já foi comentado, às vezes de choro. $\mathrm{O}$ sujeitobispo então recomenda que o sujeito respire fundo, para poder enunciar sua mudança qualitativa.

Enunciar seu nome, assumir uma identidade, nesse momento do ritual de libertação e cura, é apresentar-se para a Igreja como qualitativamente modificado, quase como outro (sendo o mesmo), livre do mal. É então o modelo ideal-típico de homem que se apresenta à frente de todos - o homem cujo jogo do Mal foi extirpado graças a sua fé no Espírito Santo; seu corpo agora está protegido contra qualquer intervenção espiritual negativa, como que vedado ao estranho, puro, limpo, liberto. Tão protegido quanto um filho-de-santo que acabou de tomar um passe. A diferençamais marcante, é claro, é o fato de o filho-de-santo continuar aberto ao preceito "vários 
espíritos numa só cabeça", enquanto o sujeito-fiel da IURD admitir como única conduta permitida "um só espírito para uma única cabeça".

Mais um traço da tradução de FD2, o misto de vergonha e alívio que os sujeitos-libertados de FD1 apresentam após o ato de exorcismo é oposto ao orgulho e respeito experimentados pelos sujeitos-cavalos de FD2.

Como se pode perceber, esse momento da interlocução Bispo $\longleftrightarrow \longrightarrow$ Fiel é o único em que o sujeito-fiel enuncia, ele próprio, sua situação, assumindo seu estatuto de sujeito-fiel em primeira pessoa. Ao fazê-lo, não só confirma o simulacro do discurso de FD2 enquanto causa de seus males, mas confirma também, fundamentalmente, o poder, a eficácia do discurso de FD1, que o possibilita enunciar sua situação como passada, superada, vencida, apresentando-se agora como sujeito-liberto.

Contudo, sua participação é parca e enfatiza prioritariamente suas privações. Não é nem um agradecimento, é como se o que lhe fosse permitido dizer nesse momento se restringisse somente à assunção de sua identidade e à imagem que lhe foi construída ao longo do ritual de libertação e cura. $\mathrm{O}$ testemunho da cura, entretanto, pode ser bastante explicito como no exemplo a seguir:

Fiel $\rightarrow$ Bispo: "Estou curada, graças a Deus".

Figura espetacular do ritual de libertação e cura, tanto como lugar do simulacro do outro, enquanto encosto, assim como exemplaridade da possibilidade de libertação, milagre, ultrapassagem entre planos temporal e divino, o sujeito-possesso/libertado é paradigma para todos os que ouvem seu desvio e seu retorno ao seio da normalidade ditada por FD1. Traço fundamental do simulacro das entidades afro, a possibilidade de ser vítima dos encostos abrange, em nível mais estrito, a todos que tiveram algum contato com as religiōes afro e, de modo mais abrangente, a qualquer um que possa ver vítima de um trabalho pago por outrem, englobando assim todo interlocutor como possível vítima e, portanto, como possível sujeitofiel de FD1. Dada a negatividade do sentido relativo às entidades afro na memória discursiva do senso comum, tal associação entidade afro $=$ diabo 
demonstra ter receptividade cada vez maior de sujeitos das mais variadas posiçôes sociais no Brasil, produzindo uma verdadeira "guerra santa no país do sincretismo".

Ainda sobre o lugar do sujeito-fiel liber to, esse se atualiza como o lugar de um eterno retorno da ação do milagre divino sobre sua necessária contra-parte: o Mal. De fato, a crença na eficácia do ritual de libertação e cura tem no sujeito-fiel libertado a ritualização sempre repetida da esperan ça e possibi lidade da vitóri a contra o Mal (e assim da confir mação da existência dominante dessas forças antagô nicas), e portan to da resposta divina aos clamores mundanos. A intervenção do Espírito Santo resolvendo os infortúnios terrestres está assim intrin secamente ligada à existência do $\mathrm{Mal}$ - dos encostos - representando-se como uma ação combativa, uma resposta à ação maléfica desses espíritos que, por sua vez, têm uma relação íntima com os sujeit os-fié is da IURD. O olhar retros pectivo do sujeito-fiel para suas prátic as religiosas anteriores, sob a perspectiva do seu novo lugar de fiel, é um olhar muito próximo ao arrepend imento, no qual "o passado não é esquecid o, desmemo rializad o. Ele é consta ntemen te atuali zado para ser diaria mente exorcizado, sempre renovado e representado no ritual do exorcismo/libertação" (Oro, 1997, p. 21).

Uma vez expulsa a alteridade negativa ${ }^{26}$, o ritual se fecha com a benção do sujeito-bispo para o sujeito-fiel libertado, para que esse não seja invadido novamente pelo mal. Assim, o sujeito-bispo pode pedir o auxílio dos sujeitos-fiéis, tal como o faz no momento do exorcismo, pedindo que estes estendam as mãos em direção ao altar, segundo um posicionamento próprio do corpo, condição necessária da eficácia da performatividade religiosa. Com as mãos na cabeça do sujeito-liberto, o sujeito-bispo enuncia a fórmula religiosa a partir do contato deste com Deus, tal como podemos observar na seguinte seqüência discursiva:

${ }^{26}$ Expulsa apenas temporariamente e, em certo sentido, nunca completamente, o que nos faz pensar na provável infelicidade do performativo capital do ritual: Sai!

Debates do NER, Porto Alegre, ano 6, N. 7, P. 11-78, JAn./Jun. 2005 
Sdr20: Meu Deus, como ministro da Tua palavra, eu abençôo a vida dele e da família, pra que a paz volte, e eles sejam mais felizes do que antes de tudo isso acontecer. Como ministro da Tua palavra, eu abençôo.

O sujeito-bispo é o único lugar enunciativo habilitado a abençoar dentro do Templo da Fé, tal poder não é compartilhado com os sujeitos-obrei$\operatorname{ros}^{27}$.

Trata-se de um enunciado performativo dotado de eficácia porque sua produção é a atualização de um conjunto de prescrições próprias de FD1, entre as quais destacamos a legitimidade da posição de sujeito-bispo, sustentada pelo reconhecimento desse lugar por parte dos sujeitos-fiéis (ou seja, o reconhecimento de uma maneira própria de enunciar a benção, de entoação da voz, de se apresentar vestido de branco, com microfone em mãos, etc.), reconhecimento esse que, ao produzir tal legitimação discursiva do locutor, daquele que fala, está na base de um desconhecimento dos mecanismos que o produzem, ou seja, só é possível a partir de uma inscrição em uma formação discursiva determinada sócio-históricamente.

Também em FD2 há um mecanismo similar de benção, porém aqui a benção é dada diretamente pela entidade, sem mediação ${ }^{28}$. A identificação do sujeito-bispo com o poder do Espírito Santo se contrapóe à presença da entidade afro enquanto detentora de fala e ação próprias, na exclusão (par-

\footnotetext{
${ }^{27}$ Espécie de auxiliar dos bispos e pastores. Responsável por variadas mediações entre esses e os fiéis, como aconselhamento, recolhimento de ofertas, distribuição de objetos consagrados e, inclusive, exorcismos.

${ }^{28}$ A seguinte seqüência discursiva exemplifica um ato de benção das religiōes afro, que lá recebe o nome de passe, sendo executado pela própria entidade incorporada:

Sdr: Muito axé, zifinho, que xunxê tenha muita luz no seu estudo, axim, que fique livre de todos problema, axim, saravá!

Donde se pode observar que aqui não há uma ritualização rígida dos sintagmas do ato de linguagem passe, devido, muito provavelmente, à imediatidade e espontaneidade do con tato com o divino. É importan te lembrar, também, o "português ruim" das entidades, que dificulta a compreensão de certas palavras. No contato com o desconhecido, há a mistificação da autoridade da entidade - se respeita por não (poder) conhecer.
}

Debates do NER, Porto Alegre, ano 6, N. 7, P. 11-78, jan./Jun. 2005 
cial) da subjetividade do sujeito-cavalo. Alguns antropólogos argumentam que este seria o ponto de ataque primordial da Igreja Universal contra as religiōes afro: seu imediatismo de soluçōes mágicas, um contato mais direto com a divindade. Isso pode explicar a profusão de atos performativos em FD1, que dão possibilidade de não só os membros da hierarquia religiosa executarem atos mágicos, mas também o próprio sujeito-fiel ${ }^{29}$. Na necessidade crescente de soluçôes pragmáticas para os problemas da vida, FD1 incorpora, traduzindo, essa característica de FD2 no seu contato do divino com o mundano, resultando daí uma concepção de sujeito religioso relativamente mais autônomo, detentor de direitos e poderes de determinação e ação sobre o mundo, ainda que tal ação esteja no nível da ação mágica, propriamente simbólica.

Uma vez abençoado o sujeito-liberto, o ritual de libertação e cura se fecha com mais uma música que indica a passagem para um outro momento, seja da Sessão do Descarrego, seja da Reunião de Libertação. Em geral, trata-se do momento da oferta, do dízimo, ou de algum informe sobre as campanhas ou correntes organizadas.

\section{CONSIDERAÇÕES FINAIS}

Ao final da investigação sobre o funcionamento discursivo do ritual de libertação e cura da IURD, ciente da possibilidade de outros olhares, devo buscar um fecho para tudo o quanto disse. O olhar que aqui apresentei é o olhar específico do discurso, do estudo do discurso religioso em Análise do Discurso. Esse é um olhar da determinação do já-dito na produção do dito, da constituição dialógica de qualquer enunciado do discurso. Nesse quadro, não há momento mais terrível do que este para pensar em incompletude da linguagem. Mas, avancemos.

${ }^{29} \mathrm{O}$ ato de determinar sua própria libertação "eu levanto minha mão e determino minha libertação" é o performativo que caracteriza mais significativamente a pretensa autonomia religiosa do sujeito-fiel iurdiano, uma vez que aprender a usar a fé só dá resultados na submissão a preceitos doutrinários. 
Dada a importância da intertextualidade no discurso religioso, pois se relaciona intrinsecamente com as Escrituras, procurei investigar relações intertextuais, interdiscursivas, de natureza diferente. Propus assim uma análise sobre a relação entre a heterogeneidade e as formas de ilusão de ultrapassagem do discurso religioso neopentecostal.

Lembro que as duas formas de ilusão de ultrapassagem descritas por Orlandi (1987) são a ultrapassagem legitima e a transgressão. Enquanto a identificação dos homens com Deus, caracterizada pelo movimento de cima para baixo, em que Deus compartilha com os homens de seu poder, é uma forma de ultrapassagem legítima para o catolicismo, a transgressão representa a forma ilegítima de ultrapassagem, pois o prazer de transgredir reside no experimentar o lugar do poder absoluto, "no exercício de uma liberdade que se quer sem limites" (Orlandi, 1987, p. 254).

$\mathrm{Na}$ análise do ritual de libertação e cura da IURD se pode ver as duas formas de ultrapassagem, como não poderia deixar de ser, em conflito. A ritualização do exorcismo sintetiza a relação entre as formas de ultrapassagem e a ilusão de reversibilidade desse discurso. Nela a verdade é construída através da denúncia da mentira, numa relação fundamental com a mentira do outro, com seu dizer, o discurso desse outro. A tal ponto que, no ritual de libertação e cura, um mecanismo de ultrapassagem legítima denuncia a não-legitimidade de uma transgressão, que concentra a produção do simulacro do discurso da formação discursiva das religiōes afro. Podemos dizer então que a produção do simulacro da alteridade do discurso neopentecostal tem como ponto chave a não-legitimidade da forma de ultrapassagem caracterizada como possessão, tão comum aos rituais afro.

Em seus trabalhos, a antropóloga Patrícia Birman tem estudado a reelaboração que os sujeitos fieis da IURD fazem de seu passado nas religiōes afro. Ela tem apresentado essa relação entre lógicas simbólicas como passagens do sujeito. Creio estar contribuindo, com esse trabalho, para uma exploração dessa passagem sob o viés discursivo, o viés da análise da determinação histórica dos sujeitos e dos sentidos através do exame da materialidade lingüística do discurso.

Através da análise, pude ler a determinação da exterioridade na produ-

Debates do NER, Porto Alegre, Ano 6, N. 7, p. 11-78, JAn./Jun. 2005 
ção dos sentidos da possessão, principalmente na historicidade do efeitosujeito que marca a instauração do lugar de dizer do outro dentro do ritual de libertação e cura. Traço fundamental do discurso iurdiano, sua FD aceita alguns saberes sobre as religiōes afro, os tem como pressupostos, mas exclui a legitimidade de uma forma de ultrapassagem própria a essas religiões. A possessão é o lugar do dizer do excluído, do mau sujeito, do efeito de retorno ao saber que transgride a Lei. Mas o dizer do outro aqui nada mais é do que o modo como o dizer de FD1 o diz. Como se observou na análise, na forma de ilusão de reversibilidade que marca a possessão, na cena enunciativa condena-se esse outro que fala no lugar do sujeito-fiel, sua alteridade, e na cena discursiva denuncia-se o Outro do discurso de FD1, através da ritualização do simulacro da ultrapassagem (traduzida para transgressão) legítima do discurso das religiōes afro.

Observo assim que o funcionamento discursivo do ritual evidencia o modo como o discurso de FD1 joga com o discurso de FD2, se aproximando dele mas distanciando-se ao mesmo tempo. $\mathrm{O}$ discurso iurdiano, desse modo, concede ao discurso do outro, das religiões afro, um lugar determinado, trabalhando-o. Esse lugar é o lugar do sujeito da transgressão própria ao ritual de libertação e cura da IURD, é o lugar em que se produz o simulacro da alteridade do discurso neopentecostal iurdiano. É, antes de tudo, o lugar da resistência ao discurso no discurso. Daí dizer-se que o discurso iurdiano brinca com fogo, apresenta fronteiras fluidas com o discurso das religiōes afro, arriscando sua identidade que, sob condição de existência, nunca vai ser assimilada a do outro.

Percebe-se assim que, na análise do ato de exorcismo, na segregação entre os sujeitos-fiéis incorporados e os sujeitos-fié is não-incorpora dos, há bastante resistência por parte dos sujeitos-encostos. Embora não falem muito, apenas quando perguntados, sua maneira de resistir às ordens do sujeito-bispo, seus grunhidos e gritos, sua resistência à cooperação no diálogo são traços que caracterizam um etos agressivo, mesmo selvagem. A resistência se justifica se lembramos da tradução da ultrapassagem legítima (no discurso de FD2) para transgressão (no ritual de libertação e cura). A possessão nas religiōes afro não é o lugar de contestação do saber 
de FD2. No ritual de libertação e cura transgredir é tocar no discurso contrário ao discurso de FD1, pois assim ele é interpretado. As marcas de sua presença pressupóem um certo nível de resistência, pois para um discurso autoritário como o discurso religioso, é importante vencer o argumento do outro, sendo uma estratégia a invocação desse ponto de divergência para corrigi-lo, denunciá-lo. A relação de forças entre os dois discursos se marca fortemente no etos do sujeito-bispo durante a tentativa de controle do sujeito-enco sto que resiste. O lugar do sujeito-encos to é o lugar de uma posição de sujeito em tensão entre as duas FDs. Segundo tenho entendido é justamente essa tensão que constrói o simulacro: o discurso religioso neopentecostal, autoritário e, por definição, tendendo a estancar a polissemia, traduz os enunciados de seu outro para eliminar a alteridade que o constitui, daí ser fundamental a divisão do sujeito de FD1 e a existência do lugar de dizer do sujeito-enco sto como lugar da contradição inscrita dentro da própria FD.

$\mathrm{O}$ momento de costura da heterogeneidade, quando se pretende expulsá-la, e o momento da confirmação da cura, da volta da unidade do sujeito marcada em sua enunciação. A intervenção do Espírito Santo elimina a possibilidade (temporariamente) da manifestação da alteridade que constitui o sujeito-fiel de FD1, repetidamente afastando aquilo que está tão próximo o tempo todo.

Se tomarmos o ritual de libertação e cura como um macro-ato de linguagem, constata-se, como decorrente desse compartilhamento de préconstruídos entre os sujeitos das duas FDs, uma simetria desse ritual com o funcionamento do passe das religiōes afro. A busca pela ultrapassagem legítima, a invocação de Deus é uma resposta, uma contra-ação, um contrapasse que se atualiza na ritualização do ato de exorcismo. Quando comparei $\mathrm{o}$ ato de exorcismo das freiras ursulinas analisado por De Certeau, se pode ver que o discurso dos exorcistas do século XVI dialogava com pedaços de discursos, com pedaços de crenças bastante heterogêneas, não havia uma ordem que indicasse uma unidade. Já o ato de exorcismo do ritual de libertação e cura da IURD é o ponto-chave da relação do discurso iurdiano com o discurso das religiōes afro. É o ato sagrado do contrafeitiço, da libertação 
do feitiço que atrasa a vida. O Mal como outro ganha visibilidade, ganha corpo e voz. Está em todo lugar, sobretudo no corpo de sujeitos divididos.

Embora se possa dizer que a relação entre as formaçōes ideológicas relativas aos saberes das religiões afro e as formações ideológicas do cristianismo em geral nunca foram de aliança, mas sim de conflito, através da denúncia das religióes afro como demoníacas, hoje esse combate discursivo toma formas determinadas pelo crescimento da Teologia da Prosperidade, o que o torna sensivelmente diferente de quando o Estado condenou as práticas religiosas afro ou da perseguição do catolicismo colonial. Voltando à oferta abundante de magia do catolicismo colonial, o discurso neopentecostal racionaliza o uso da fé para obtenção de bens materiais e saúde. O ritual de libertação e cura pode ser lido como um contra-passe que identifica, a um só tempo, religiōes afro $=\mathrm{Mal}=$ pobreza, doença, vícios, etc. Tomado como único passe legítimo, o ritual de libertação e cura busca eliminar a concorrência da oferta de magia para solucionar os problemas diários que se impóem à existência de muitos de nós sob o capitalismo. A concepção de Mal se alarga, se torna visível aos olhos dos fiéis e é uma ameaça à saúde e à prosperidade; a fé se transforma na condição para o consumo.

A racionalização da fé dá lugar ao pragmatismo aliado ao milagre. Um milagre que busca purificar o sujeito da alteridade que o priva da prosperidade. Velhos santos de alhures, agora demônios, apresentam-se com roupas e intenções novas, identificados à figura necessária do Diabo, que marca o outro lado da dicotomia Bem/Mal no cristianismo. O novo evangelho, a boa-nova de hoje, longe de representar ecumenismo, tolerância, é a acusação da presença ativa da alteridade e, sobretudo, a oferta da via para suportar e vencer o sofrimento: livrar-se do outro, classificá-loe condená-lo através do contrato com o Espírito Santo. Comparado muitas vezes com um guarda-chuva, na IURD o Espírito Santo faz as vezes de um guarda-costas imbatível e imprescindível para os fiéis ávidos de prosperidade e saúde, que agora têm que se haver não só com seus semelhantes, mas com os simulacros de deuses que são seus algozes. 


\section{REFERENNCIAS}

ALMEID A, Ronaldo. A guerra das possessões. In: ORO, Ari ; CORTEN, André ; DOZON, Jean-Pierre (orgs.). Igreja Universal do Reino de Deus : Os novos conquistadores da fé. São Paulo: Paulinas, 2003.

ALTHUSSER, Louis. Aparelhos Ideológicos de Estado. 8. ed., Rio de Janeiro, Graal, 2001. AUSTIN, John L. Quando Dizer é Fazer. Porto Alegre: Artes Médicas, 1990.

AUTHIER-REVUZ, Jacqueline. Hétérogeneité montrée et hétérogeneité constitutive: élements pour une approche de l'autre dans le discours. DRLAV, 26, 1978, pp. 91-151.

BAKHTIN, Mikhail (VOLOCHINOV). Marxismo e Filosofia da Linguagem. 10. ed. São Paulo: Hucitec, 2002.

BARROS, Mônica do Nascimento. A batalha do Armagedom: uma análise do repertório mágico-religioso proposto pela Igreja Universal do Reino de Deus. Belo Horizonte, UFMG, 1995. Dissertação de Mestrado.

BASTIDE, Roger. Estudos afro-brasileiros. São Paulo: Perspectiva, 1973.

BENVENISTE, Émile. "Da subjetivid ade na linguagem”. In: Problemas de lingüistica geral 1. Campinas, São Paulo: Pontes/ Editora da Unicamp, 1991, 3. ed. pp. 284-293.

BIRMAN, Patrícia. Cultos de possessão e pentecostalismo no Brasil: passagens. Religião e Sociedade. Rio de Janeiro, ISER, v. 17, nn. 1/2, pp. 90-109, 1996.

Passos n. 34.

O que é umbanda. São Paulo: Abril Cultural/Brasiliense, 1985. Coleção Primeiros

BROOK, Peter. O teatro e seu espaço. Rio de Janeiro: Vozes, 1970.

CORRÊA, Manoel Luiz G. As vozes prementes. 2. ed., Campinas: Editora da UNICAMP, 1989.

CORTEN, André. Alchimie politique du miracle: discours de la guérison divine et langue politique en Amérique latine. Montréal/Québec: L’Univers des discours, 1999.

COURTINE, Jean-Jacques. Analyse du discours politique. Langages, n. 62, Larousse: Paris, juin 1981.

DE CERTEAU, Michel. A linguagem alterada. In: . A Escritura da História. Rio de Janeiro: Forense Universitária, 1982.

. The possession at Loudun. Chicago: The University of Chicago Press, 2000.

DELEUZE, Gilles. A lógica do sentido. São Paulo: Editora da USP, 1974.

DUCROT, Oswald. "Esboço de uma teoria polifônica da argumentação". In: $O$ dizer e $o$ dito. Campinas, São Paulo, 1987, pp. 161-218.

FOUCAULT, Michel. A Arqueologia do Saber, 7. ed., Rio de Janeiro: Forense Universitária, 2004.

Debates do NER, Porto Alegre, Ano 6, N. 7, P. 11-78, jan./Jun. 2005 
A ordem do discurso, 7. ed., São Paulo: Loyola, 2001.

. Vigiar e Punir: o nascimento da prisāo. Petrópolis: Vozes, 1987.

. Microfisica do Poder. Rio de Janeiro, Graal, 1979.

FRESTON, Paul. Breve história do pentecostalismo brasileiro. In: ANTONIAZZI, Alberto et alii. Nem anjos nem demônios: interpretaçôes sociológicas do pentecostalismo. Petrópolis: Vozes, 1994. pp. 67-99.

GADET, F.; HAK, T. (Orgs.). Por uma análise automática do discurso. 3. ed. Campinas: Editora da Unicamp, 1997.

GREGOLIN, Maria do Rosário. Foucault e Pêcheux na construção da análise do discurso: diálogos e duelos. São Carlos: ClaraLuz, 2004.

GUIMARÃES, Eduardo. Semântica do Acontecimento. Campinas: Pontes, 2002.

HENRY, Paul. Construçōes relativas e articulaçōes discursivas. Cadernos de Estudos Lingüisticos, n. 19, pp. 43-64. Campinas, IEL, UNICAMP, 1990.

INDURSKY, Freda. A fala dos quartéis e as outras vozes. Campinas: Editora da UNICAMP, 1997.

MACEDO, Edir. Orixás, Caboclos e Guias: Deuses ou Demônios? Rio de Janeiro: Universal Produçôes, 2002.

MAINGUENEAU, Dominique. Genèses du discours. Bruxelas, Pierre Mardaga, Editeur, 1984.

L'analyse du discours : Introduction aux lectures de l'archive. Paris, Hachette, 1991.

MALDIDIER, Denise. (Re)lire M. Pêcheux aujopurd'hui. In : PÊCHEUX, M.

L'inquietude du discours. Textes choisis et présentés par D. Maldidier. Paris: Cendres, 1990.

MARIANO, Ricardo. A Igreja Universal no Brasil. In: ORO, Ari ; CORTEN, André; DOZON, Jean-Pierre (orgs.). Igreja Universal do Reino de Deus: Os novos conquistadores da fé. São Paulo: Paulinas, 2003, pp 53-67.

NETO, F. RIVAS. Liçôes Básicas de Umbanda. Rio de Janeiro: Freira Bastos, 1991.

ORO, Ari.Pedro (org.). As religiōes afro-brasileiras do Rio Grande do Sul. Porto Alegre: Editora da Universidade (UFRGS), 1994.

O Espírito Santo e o Pentecostalismo. Teocomunicação, Porto Alegre, v. 25 - no. 107, Março 1995, pp. 87-101. . Avanço Pentecostal e Reação Católica. Porto Alegre: Vozes, 1996.

"Neopentecosta is e Afro-brasileiros: quem ven cerá esta guerra?", Debates do NER, Porto Alegre, Ano 1, n. 1, 1997, pp. 10-36. 
. O "Neopentecostalismo Macumbeiro", um estudo acerca do embate entre a Igreja Universal e as Religióes Afro-brasileiras. Texto apresentado em Mesa Redonda no $24^{\circ}$ congresso da Associação Brasileira dos Antropólogos, Recife, 2004.

ORO, Ari Pedro; CORTEN, André; DOZON, Jean-Pierre (orgs.). Igreja Universal do Reino de Deus : Os novos conquistadores da fé. São Paulo: Paulinas, 2003.

ORLANDI, Eni. A linguagem e seu funcionamento: as formas do discurso. 2. ed., Campinas: Pontes, 1987.

. Interpretação: leitura e efeitos do trabalho simbólico. 2. ed. Petrópolis: Vozes, 1998.

PÊCHEUX, Michel. Discurso, estrutura ou acontecimento, 3. ed., Campinas: Pontes, 2002. . Semântica e Discurso: uma crítica à afirmação do óbvio. 2. ed. Campinas: Editora da Unicamp, 1995.

. Análise automática do discurso (AAD-69). IN: GADET, F; HAK, T. (Orgs.). Por uma análise automática do discurso. 3. ed. Campinas: Editora da Unicamp, 1997.

Effects discursifs liés au fonctionnement des relatives en français. Recherches en

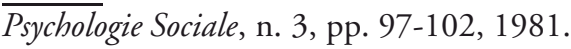

PECCHEUX, Michel ; FUCHS, Catherine. A propósito da análise automática do discurso : atualização e perspectivas. IN: GADET, F.; HAK, T. (Orgs.). Por uma análise automática do discurso. 3. ed. Campinas: Editora da Unicamp, 1997.

REBOUL, Olivier. Langage et Idéologie, PUF, Paris, 1980.

RIBEIRO, Jaçanã. O simulacro da alteridade: uma análise discursiva do ritual de libertação e cura da Igreja Universal do Reino de Deus. Dissertação (mestrado em Estudos da Linguagem - Análise de Discurso) apresentada ao PPG-Letras da UFRGS, Porto Alegre, 2005, $215 \mathrm{f}$.

SILVEIRA, Verli F. Petri. Imaginário sobre o gaúcho no discurso literário: da representação do mito em Contos gauchescos, de João Simões Lopes Neto, à desmitificação em Porteira Fechada, de Cyro Martins. Tese (doutorado em Análise de Discurso) apresentada ao PPG-Letras da UFRGS, Porto Alegre, 2004, $357 \mathrm{f}$.

SITE: <http://www.arcauniversal.com.br>

TODOROV, Tzvetan. Mikahïl Bakhtine: le principe dialogique. Paris : Éditions du Seuil, 1981. 